\title{
Design, Synthesis and Biological Evaluation of Neogliptin, a Novel 2-Azabicyclo[2.2.1]heptane-Based Inhibitor of Dipeptidyl Peptidase-4 (DPP-4)
}

\author{
Ivan O. Maslov ${ }^{1}{ }^{(}$, Tatiana V. Zinevich ${ }^{1}$, Olga G. Kirichenko ${ }^{2}$, Mikhail V. Trukhan ${ }^{3}{ }^{\mathbb{D}}$, Sergey V. Shorshnev ${ }^{4}$, \\ Natalya O. Tuaeva ${ }^{3,5}{ }^{(}$, Maxim A. Gureev ${ }^{6,7} \mathbb{D}^{\text {, }}$, Amelia D. Dahlén ${ }^{8}$, Yuri B. Porozov ${ }^{6,7}$, Helgi B. Schiöth ${ }^{3,8, *}$ \\ and Vladimir M. Trukhan ${ }^{3, *(1)}$
}

check for updates

Citation: Maslov, I.O.; Zinevich, T.V.; Kirichenko, O.G.; Trukhan, M.V.; Shorshnev, S.V.; Tuaeva, N.O.; Gureev, M.A.; Dahlén, A.D.; Porozov, Y.B.; Schiöth, H.B.; et al. Design, Synthesis and Biological Evaluation of Neogliptin, a Novel 2-Azabicyclo[2.2.1]heptane-Based Inhibitor of Dipeptidyl Peptidase-4 (DPP-4). Pharmaceuticals 2022, 15, 273. https://doi.org/10.3390/ph15030273

Academic Editors: Jean

Jacques Vanden Eynde and

Angela De Simone

Received: 25 November 2021

Accepted: 20 February 2022

Published: 22 February 2022

Publisher's Note: MDPI stays neutral with regard to jurisdictional claims in published maps and institutional affiliations.

Copyright: (C) 2022 by the authors. Licensee MDPI, Basel, Switzerland. This article is an open access article distributed under the terms and conditions of the Creative Commons Attribution (CC BY) license (https:// creativecommons.org/licenses/by/ $4.0 /)$.
1 Department of Bioorganic chemistry, Faculty of Biology, Lomonosov Moscow State University, 119991 Moscow, Russia; ivan.maslov@monash.edu (I.O.M.); zinevich.tatiana@gmail.com (T.V.Z.)

2 LLC Institute of Mitoengineering MSU, 119899 Moscow, Russia; kirolga2001@mail.ru

3 Institute for Translational Medicine and Biotechnology, I. M. Sechenov First Moscow State Medical University, 119991 Moscow, Russia; trukhan.misha@gmail.com (M.V.T.); natalya.tuaeva@gmail.com (N.O.T.)

4 Chembridge Corp., 119435 Moscow, Russia; gray20002006@yandex.ru

5 Serbsky Institute for General and Forensic Psychiatry, 119839 Moscow, Russia

6 World-Class Research Centre "Digital Biodesign and personalised healthcare", I. M. Sechenov First Moscow State Medical University, 119991 Moscow, Russia; max_technik@mail.ru (M.A.G.); yuri.porozov@gmail.com (Y.B.P.)

7 Department of Computational Biology, Sirius University of Science and Technology, Olympic Ave 1, 354340 Sochi, Russia

8 Functional Pharmacology and Neuroscience, Department of Surgical Sciences, Uppsala University, 75124 Uppsala, Sweden; dahlenamelia@gmail.com

* Correspondence: helgi.schioth@neuro.uu.se (H.B.S.); vladimir.trukhan@gmail.com (V.M.T.)

Abstract: Compounds that contain (R)-3-amino-4-(2,4,5-trifluorophenyl)butanoic acid substituted with bicyclic amino moiety (2-aza-bicyclo[2.2.1]heptane) were designed using molecular modelling methods, synthesised, and found to be potent DPP-4 (dipeptidyl peptidase-4) inhibitors. Compound 12a $($ IC50 $=16.8 \pm 2.2 \mathrm{nM})$, named neogliptin, is a more potent DPP-4 inhibitor than vildagliptin and sitagliptin. Neogliptin interacts with key DPP-4 residues in the active site and has pharmacophore parameters similar to vildagliptin and sitagliptin. It was found to have a low cardiotoxic effect compared to sitagliptin, and it is superior to vildagliptin in terms of ADME properties. Moreover, compound 12a is stable in aqueous solutions due to its low intramolecular cyclisation potential. These findings suggest that compound 12a has unique properties and can act as a template for further type 2 diabetes mellitus drug development.

Keywords: type 2 diabetes mellitus; DPP-4 inhibitors; molecular docking; structure-activity relationship; stereoisomerism; rotameric forms

\section{Introduction}

Pharmacological therapy for type 2 diabetes mellitus (T2DM) patients has developed considerably over the past decades involving several new strategies [1-3]. Many of these strategies involve more patient-friendly ways of drug administration. Several decades ago, insulin injections were the only way to overcome hyperglycaemia, but now many oral antihyperglycaemic agents are available that are administrated either in monotherapy or as combinational drug therapy. Currently, one of the most recent and promising methods to treat T2DM is to use dipeptidyl peptidase 4 (DPP-4) inhibitors, which are also called gliptins [4-9]. They prevent the degradation of glucagon-like peptide-1 (GLP-1) and glucose-dependent insulinotropic peptide (GIP), stimulate insulin synthesis, suppress glucagon secretion, inhibit appetite, reduce body weight, slow gastric emptying, and can 
restore functions of pancreatic beta cells providing a new approach that is effective for T2DM patients.

DPP-4 is a glycoprotein expressed in several tissues that has a catalytic activity selective for protein molecules that contain Pro or Ala in the penultimate position at the $\mathrm{N}$-terminus; it plays a vital role in several functions, including immune regulation, signal transduction, and apoptosis as well as being used by MERS-CoV as a receptor [10]. DPP-4 consists of 766 amino acids (aa) and comprises several parts: intracellular (6 aa), transmembrane (22 aa), and large extracellular (738 aa) with a catalytic site. Two identical DPP-4 glycoproteins are usually located near each other and form a dimer. Each subunit is composed of $\alpha / \beta$-hydrolase and $\beta$-propeller domains, and they form a cavity that is crucial for inhibitor binding $[6,11]$.

Currently, several structures oriented to target-specific interaction with DPP-4 are already known and officially approved by the U.S. Food \& Drug Administration (FDA), including sitagliptin [12], saxagliptin [13], alogliptin [14], and linagliptin [15] (Table 1). All these DPP-4 inhibitors are used both in monotherapy, such as Januvia (sitagliptin), Onglyza (saxagliptin), Nesina/Vipidia (alogliptin), Trajenta (linagliptin), and in combinations with other antihyperglycaemic drugs. The FDA-approved combinations with DPP-4 inhibitors include Janumet (sitagliptin and metformin), Jentadueto (linagliptin and metformin), Kazano (alogliptin and metformin), Steglujan (sitagliptin and ertugliflozin), Qtern (saxagliptin and dapagliflozin), Glyxambi (linagliptin and empagliflozin), Oseni (alogliptin and pioglitazone) and Qternmet XR (saxagliptin, metformin, and dapagliflozin).

Some other gliptins (e.g., vildagliptin, teneligliptin, trelagliptin, evogliptin, omarigliptin) have not been yet approved by the FDA (Table 1), but they are nevertheless marketed in many countries and used as T2DM treatment. Moreover, several DPP-4 inhibitors are in the final phases of clinical trials. In recent years, studies of drugs' physiological profiles and clinical properties based on DPP-4 inhibitors have been intensively and widely conducted and the side effects that such drugs may cause. Although the four approved DPP-4 inhibitors share good properties, such as antihyperglycaemic activity, the lack of bodyweight influence, and low risk of hypoglycaemia, some specific side effects such as hepatotoxicity or cardiotoxicity [16], and adverse reactions should be considered. Moreover, the importance of providing individualised patient care for safe and effective antihyperglycaemic therapies has also been highlighted. That is why there is still strong enthusiasm in developing novel inhibitors of DPP-4 with more favourable side effects profiles, different pharmacokinetic properties, or cheaper to manufacture.

Over the last years, several new DPP-4 inhibitors have been published, many of which are very potent in the low nanomolar range of IC50 values. Different scaffolds have been closely studied to search for new active DPP-4 inhibitors. In silico methods are widely used at the early stages of drug design as they provide an opportunity to reduce the number of molecules needed to be screened [8,17]. Some strategies of DPP-4 inhibitor design, like ligand-based and structure-based virtual screening, utilise computer-aided drug discovery methods, allowing to prioritise the space of small molecules, using a series of patterns, calculated in accordance to protein active site structure data and its ligands [11,18-26]. Many experiments were carried out on the structural characterisation of synthesised or natural compounds using high-throughput methods.

Here we performed virtual screening and created structure-activity relationship (SAR) models to reveal new potent DPP-4 inhibitors. In this article, we present a novel class of small-molecule derivatives based on 3-azabicyclo[2.2.1] heptene-2-carbonitrile that seems to be promising agents to treat hyperglycaemia. 
Table 1. The U.S. Food and Drug Administration (FDA) structures and approval of the most common DPP-4 inhibitors.

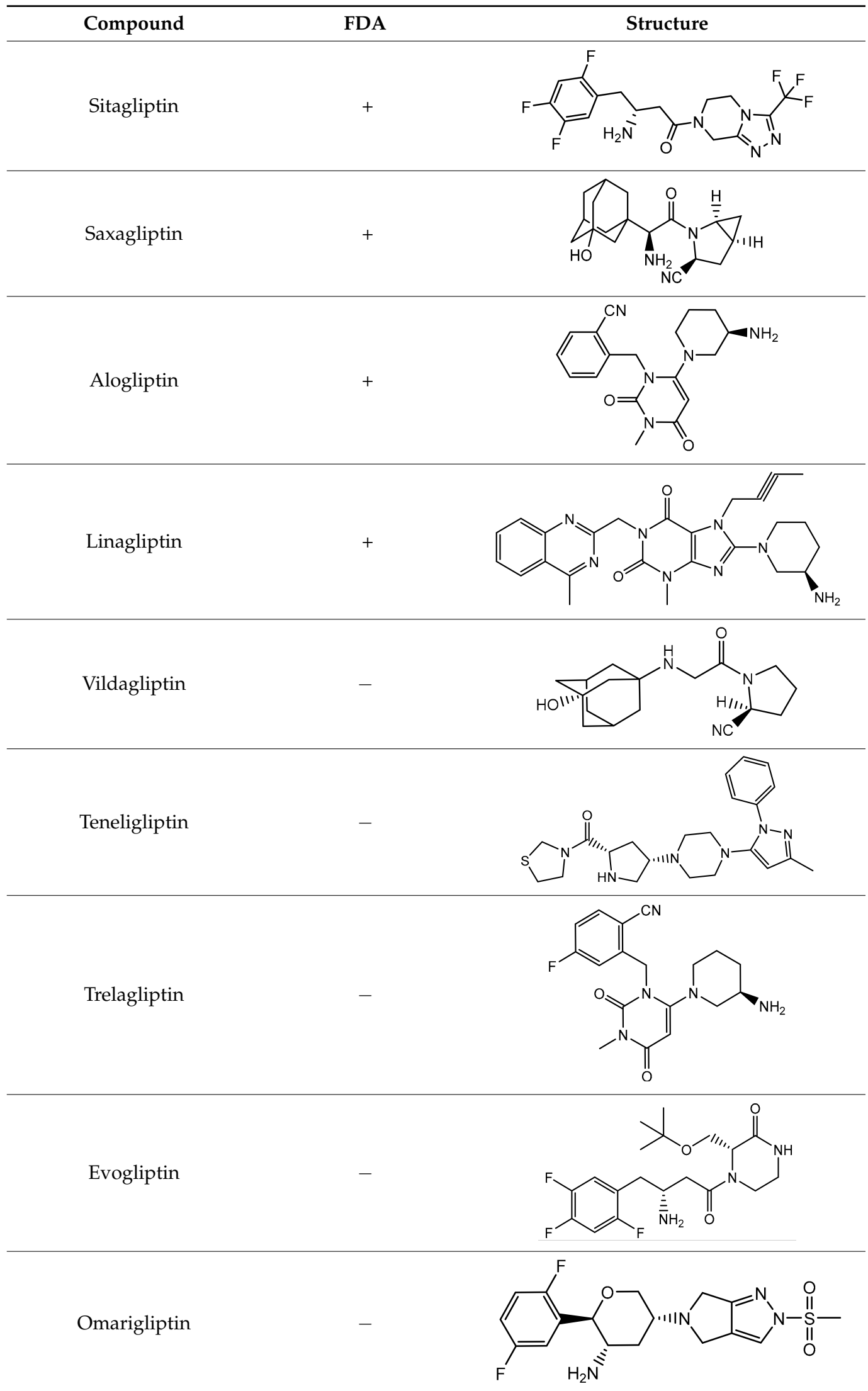




\section{Results and Discussion}

\subsection{Molecular Modelling}

We initially analysed analogous compounds that contain the same beta-amino acid ((R)-3-amino 4-(2,4,5-trifluorophenyl)butanoic acid) and bicyclic amino moiety (2-azabicyclo[2.2.1] heptane) with a nitrile substituent. We performed molecular modelling predictions and compared the predicted DPP-4 inhibition activity of these compounds. We looked particularly at the presence of spontaneous intramolecular cyclisation previously described for the acylated cyanopyrrolidine derivatives [27]. This intramolecular cyclisation leads to the formation of substituted diketopiperazines with no affinity to DPP-4 (Figure 1).<smiles>[R]NCC(=O)N1CCC[C@H]1C#N</smiles>

Figure 1. Spontaneous intramolecular cyclisation of the cyanopyrrolidine derivatives acylated with alpha-amino acids.

To avoid these negative consequences, we had an idea to modify the cyanopyrrolidine moiety by adding the second aliphatic cycle to make this part less flexible. The same unsymmetric ring system described in [28] for ledipasvir demonstrated beneficial SAR properties compared to pyrrolidine-based analogues. We also decided to prefer betaamino acid (the same as the one in sita- and evogliptin) instead of alpha derivatives because of the enlargement of the aliphatic chain that connects cyanopyrrolidine moiety with the amino group that is crucial in protein-ligand interaction leads to energetically unfavourable cyclisation reaction profiles. The presence of chiral centre in 3-position of 2-aza-bicyclo[2.2.1] heptane results in two isomeric structures of exo- and endo-configuration (Figure 2).
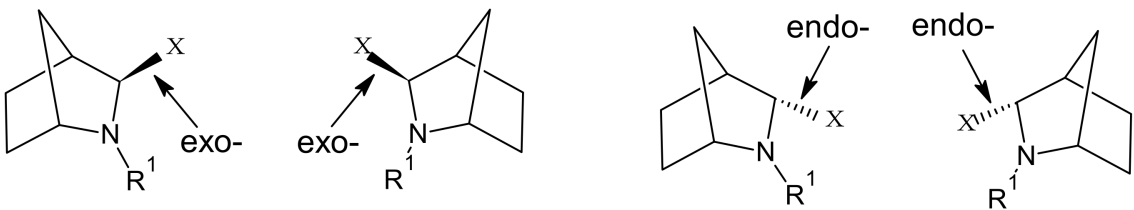

Figure 2. Possible stereoisomers of 3-substituted 2-aza-bicyclo[2.2.1]heptanes.

Next, we analysed protein-ligand binding modes and spatial orientation of reference compounds in terms of functional groups needed for correct ligand-protein interaction (Figure $3 a, b)$. Amino acids in the active site of DPP-4 form different subsites (S2, S1, S'1, and $S^{\prime} 2$ ) that are usually occupied by different residues of the substrate molecule. The S1 pocket is formed predominantly by S630, D708, H740 (a catalytic triad), Y631, V656, W659, Y662, Y666, V711. Meanwhile, the S'2 pocket consists of R125, E205, E206, S209, F357. Critical residues of $S^{\prime} 1$ and $S^{\prime} 2$ binding pockets are Y547 and W629, respectively. Sitagliptin (S) and vildagliptin (V), the two earliest DPP-4 inhibitors approved, occupy the active centre differently (Figure 3). Due to the structural dissimilarity, they have differences in DPP-4 binding site filling efficiency $(\mathrm{S}>\mathrm{V})$, ability to form pi-stacking interaction with aromatic groups $(\mathrm{S}>\mathrm{V})$, hydrophobic contacts intensity $(\mathrm{S}>\mathrm{V})$, and hydrogen bonding intensity $(\mathrm{S}<\mathrm{V})$.

Our new compound 12a has shown the following protein-ligand interaction profile: Residues in S'1 and S'2 binding pockets are involved in hydrophobic interactions. Trifluorophenyl aromatic ring forms significant hydrophobic site-specific interaction in S1 and S2 pockets using crucial $\pi-\pi$ stacking interactions with tyrosine sidechains and hydrogen bonds with E205/E206. Trifluorophenyl ligand moiety partially occupies the S1 pocket, 
thus forming $\pi-\pi$ stacking with Y666/Y662 and H740. Additional aliphatic cycle allows 12a to form hydrophobic interactions with residues in the S2 extensive region.

Also, 12a contains the cyanopyrrolidine moiety and, thus, mimics the penultimate proline of DPP-4 substrates; its nitrile moiety is targeted to occupy the $S^{\prime} 1$ binding pocket. This interaction mediates the formation of a hydrogen bond with Arg669 in the S'1 pocket. Here, the nitrile group is a non-covalent interactant [29] and an important part of the site-specific interaction machinery (as in vildagliptin, Figure 3).

\section{(a)}

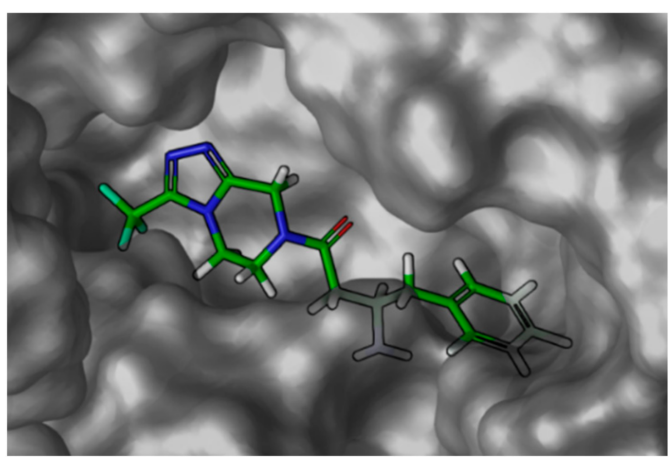

Sitagliptin, $1 \mathrm{X} 70, \mathrm{IC}_{50}=18 \mathrm{nM}$

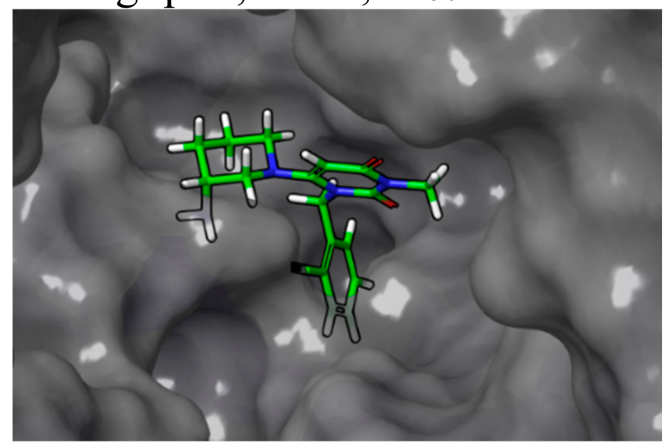

Trelagliptin, $5 \mathrm{KBY}, \mathrm{IC}_{50}=2 \mathrm{nM}$

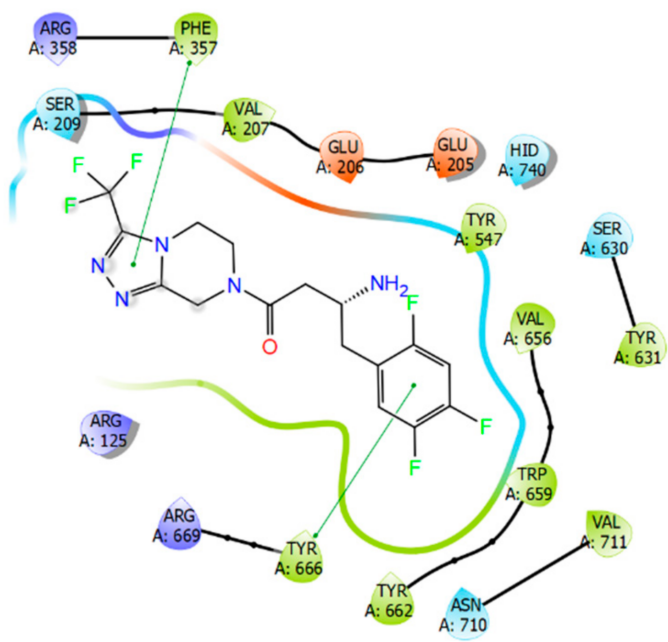

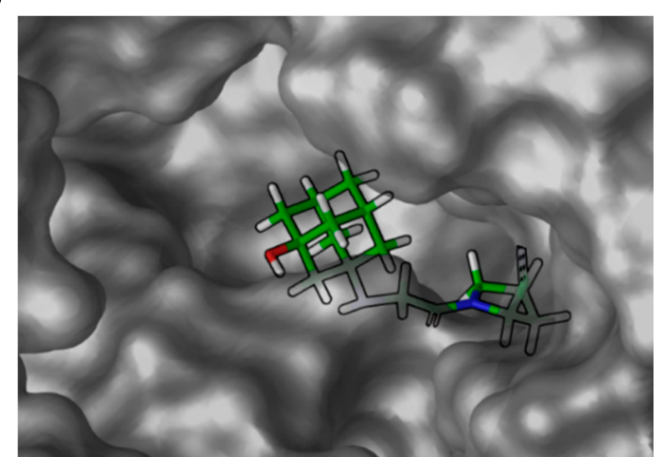

Vildagliptin, $6 \mathrm{~B} 1 \mathrm{E}, \mathrm{IC}_{50}=29.2 \mathrm{nM}$

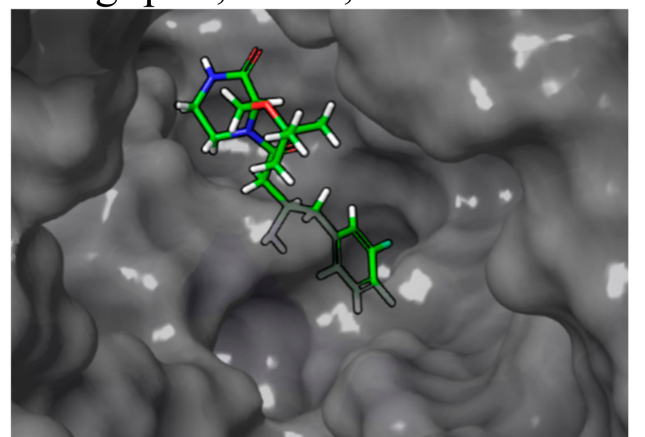

Evogliptin, $5 \mathrm{Y} 7 \mathrm{~K}, \mathrm{IC}_{50}=0.9 \mathrm{nM}$

(b)

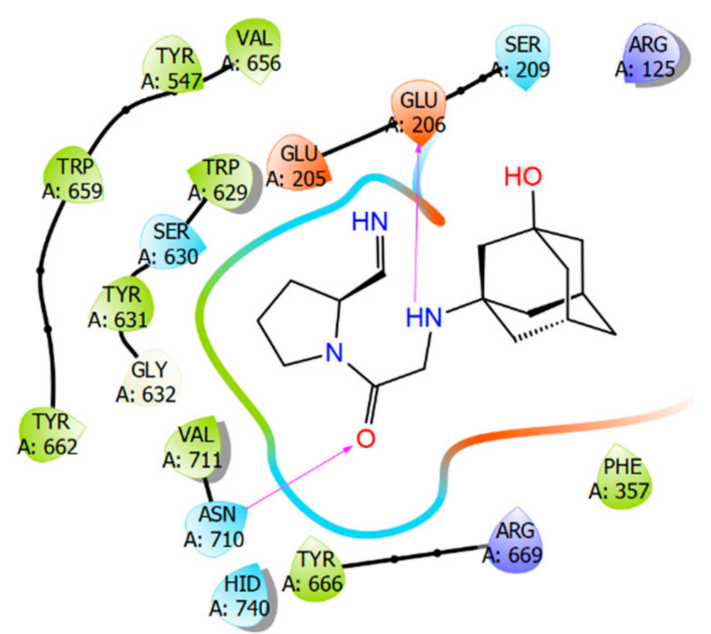

Figure 3. Cont. 

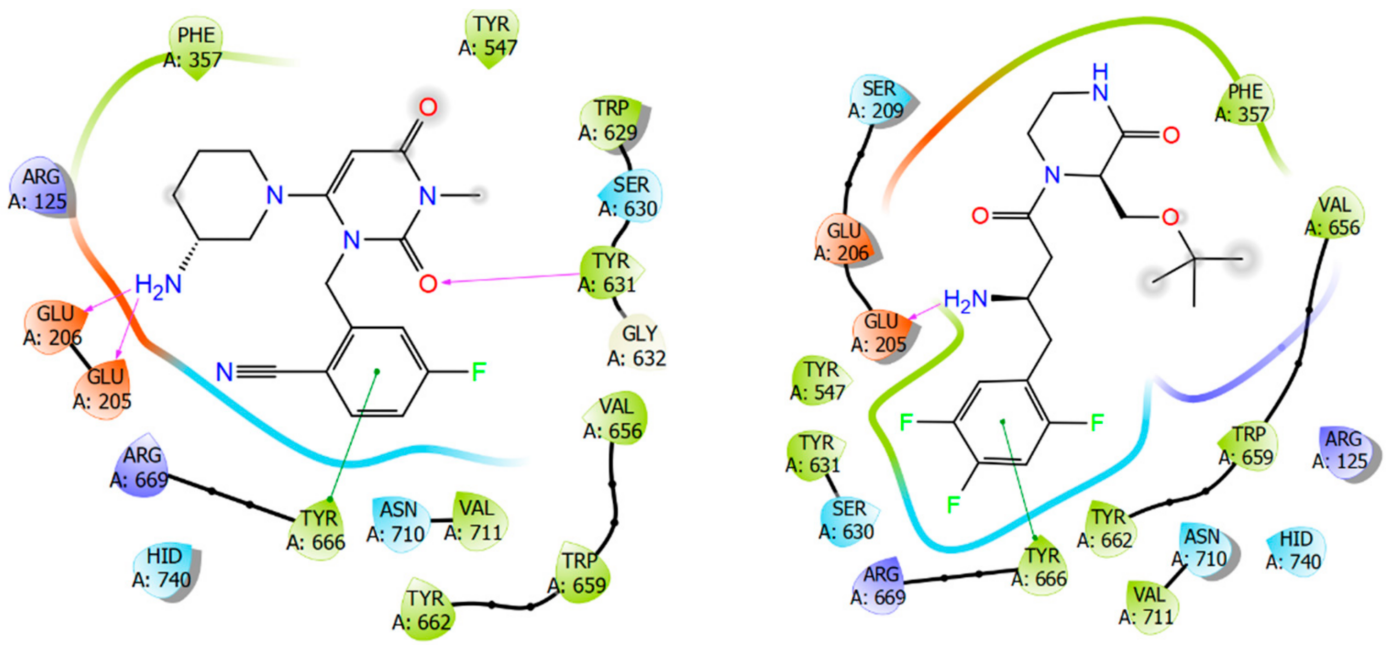

Figure 3. Binding parameters of most potent reference compounds. (a)-inhibitors in the DPP-4 binding cavity, (b)-ligand interactions diagram, showing the essential interacting residues. [Colour Figure 4. demonstrate that compound 12a has interaction patterns similar to sitagliptin and vildagliptin. This fact is also complemented by scoring function values (Table 2). Although 12a has GlideScore and Emodel values within the same range as for reference structures, its $\Delta$ Gbind value is preferred, indicating that the protein-ligand complex of DPP-4 with 12a is energetically more favourable. Moreover, the predicted parameter of potential cardiotoxicity (QPlogHERG, blocking of HERG K+ ion channels) for 12a is the safest. Sitagliptin has the highest risk of potential cardiotoxicity (the reference value less than -5 may result in high cardiotoxicity). Some reviews and clinical trials showed conflicting findings of this effect [30-32]. Predicted cardiotoxicity of 12a is comparable to vildagliptin, which does not cause side effects associated with heart failure [33]; 12a is also predicted to have a 1.5-fold reduced cardiotoxicity than sitagliptin. Thus, the new compound 12a unifies the binding parameters of two known active DPP-4 inhibitors, and at the same time, is predicted to be less toxic. As can be seen in Figure 4, non-active compound $\mathbf{1 2 b}$ binds in reversed, incorrect mode. This fact is linked with steric incompatibility with the active cleft of DPP-4. The same applies to compounds 12c,d.

Additionally, this fact is confirmed with MM-GBSA free energy calculations (Table 2), compounds $\mathbf{1 2 b}-\mathbf{d}$ showed a significant increase in free Gibbs $(\Delta G)$ energy, which would result in the unfavourability of ligand-protein complex with DPP-4 (also confirmed by docking results). We observed a loss in site-specificity that resulted in the absence of some protein-ligand interactions that are typical for reference compounds (see Figure 3).

Table 2. Scoring results of re-docked reference structures, comparison with best-fitting compound 12a and non-active 12b-d. Higher risk of potential cardiotoxicity is highlighted in yellow and lower risk of potential cardiotoxicity is highlighted in green.

\begin{tabular}{|c|c|c|c|c|}
\hline Structure & GlideScore & Emodel & $\Delta \mathrm{G}_{\text {bind }}(\mathrm{kcal} / \mathrm{mol})$ & QPlogHERG \\
\hline Sitagliptin & -5.80 & -63.96 & -17.05 & -4.351 \\
\hline Trelagliptin & -5.68 & -54.94 & -16.35 & -5.078 \\
\hline Evogliptin & -5.84 & -53.11 & -17.02 & -3.032 \\
\hline Vildagliptin & -5.99 & -56.58 & -16.60 & -2.987 \\
\hline $12 \mathrm{a}$ & -5.74 & $-59,69$ & -17.39 & -2.884 \\
\hline $12 b$ & -4.01 & -40.56 & -5.14 & -3.191 \\
\hline $12 \mathrm{c}$ & -3.69 & -37.24 & -9.09 & -3.010 \\
\hline $12 \mathrm{~d}$ & -3.70 & -45.46 & -3.43 & -3.393 \\
\hline
\end{tabular}

Predicted IC50 value for blockage of HERG K+ channels (QPlogHERG). 


\subsection{Chemical Synthesis}

The general synthetic route for preparing the key intermediates, $R / S$-Exo- and $R / S$-endo3-azabicyclo[2.2.1] heptane-2-carbonitriles, is shown in Figures 5 and 6. Initially, starting from cyclopenta-1,3-diene (1), ethyl oxoacetate (2), and ammonia chloride, a mixture of four different stereoisomeric compounds (3a-d) were obtained [34-36]. Subsequent treatment of the mixture with Boc2 $\mathrm{O}$ followed by column chromatography procedure afforded the separation of exo- and endo-isomeric pairs $4 \mathbf{a}, \mathbf{b}$ and $4 \mathbf{c}, \mathbf{d}$ (Figure 5) [37].

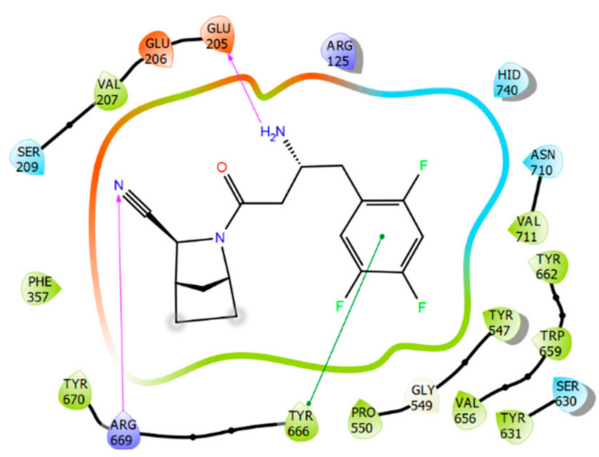

$12 a$

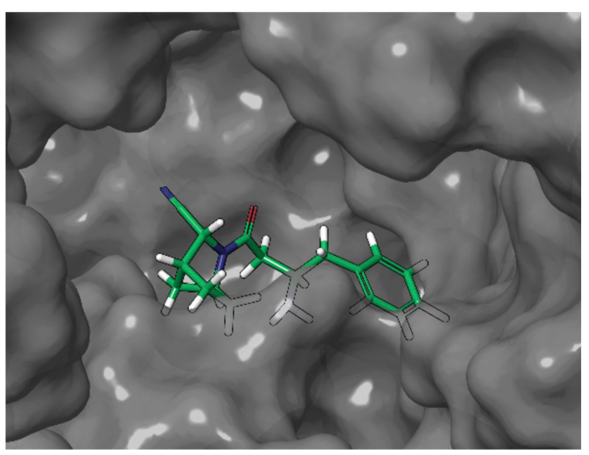

(b)

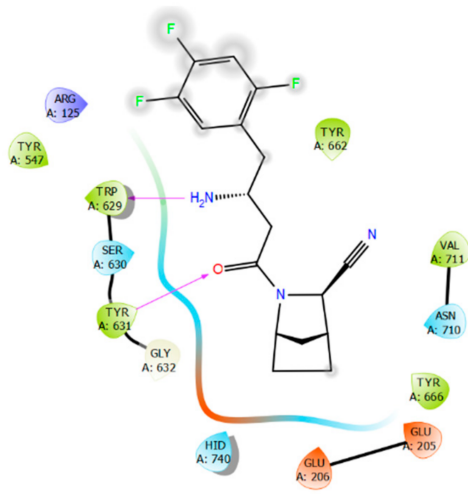

$\mathbf{1 2 b}$ (non-active)

(a)

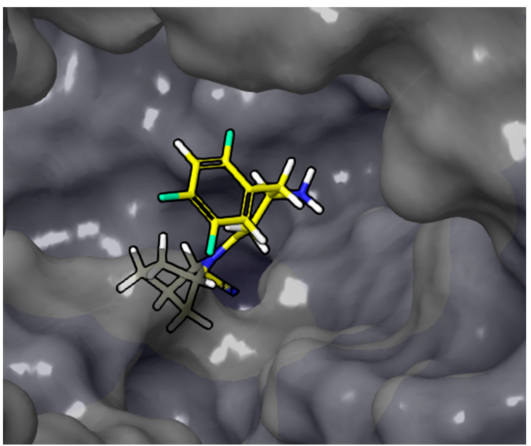

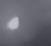

Figure 4. Ligand interaction diagram of $\mathbf{1 2} \mathbf{a}, \mathbf{b}$ in the active site of DPP-4 (a) and ligand positioning in DPP-4 binding cavity (b).

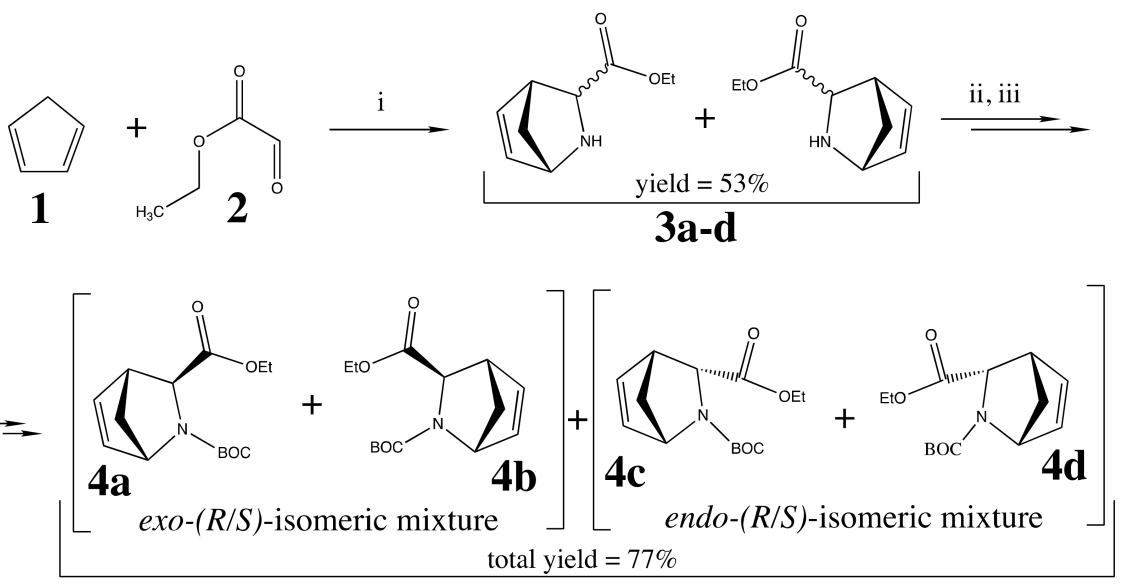

Figure 5. Synthesis of intermediates $4 \mathbf{a}, \mathbf{b}$ and $4 \mathrm{c}, \mathrm{d}$. Reagents and conditions: (i) sat. $\mathrm{NH}_{4} \mathrm{Cl}$ for $12 \mathrm{~h}$ at rt; (ii) $\mathrm{Boc}_{2} \mathrm{O}$, THF overnight at rt (iii) separation by column chromatography, gradient: petroleum ether $(\mathrm{PE}) \rightarrow 30 \%$ EtOAc in PE. 


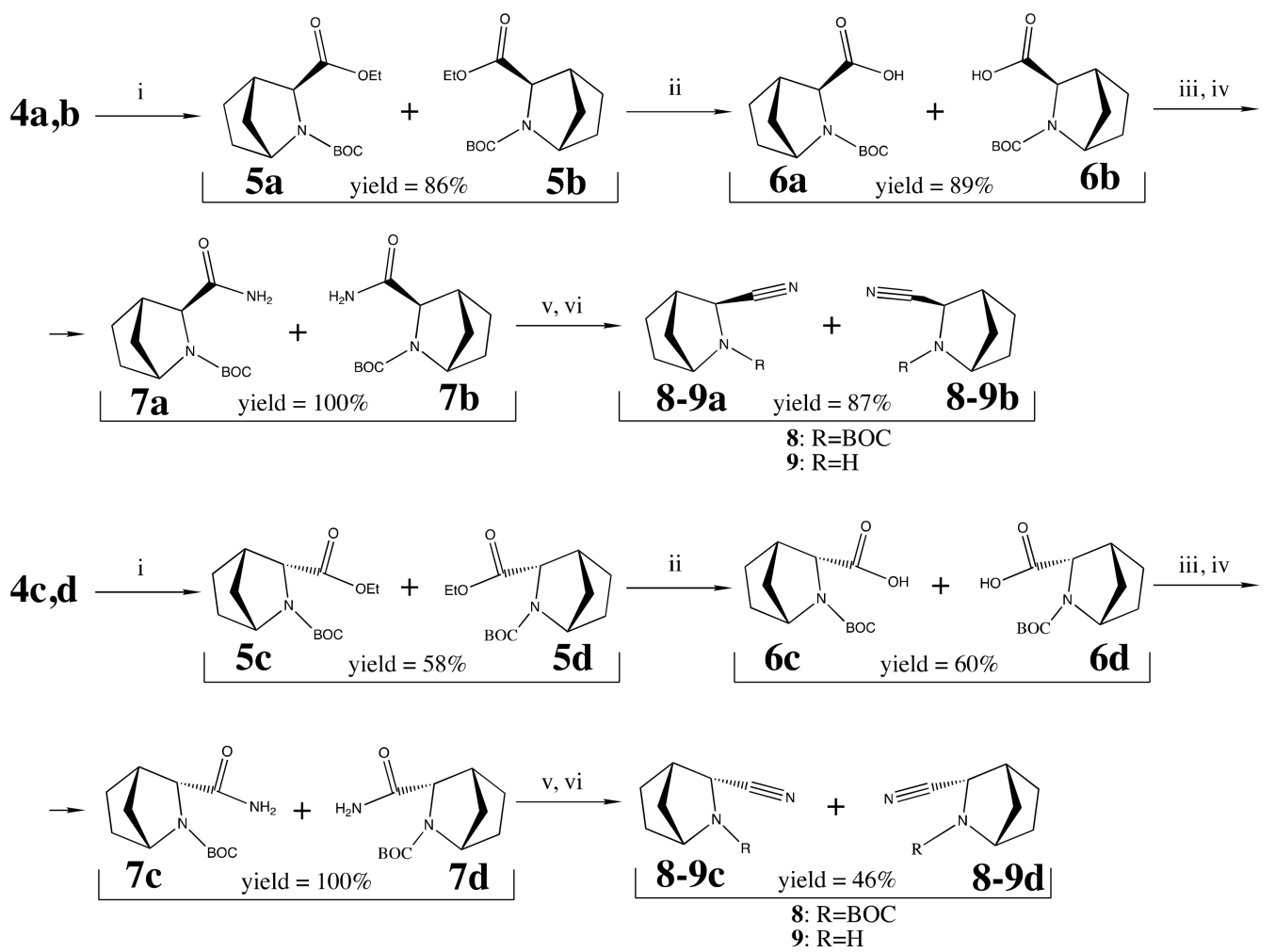

Figure 6. Synthesis of exo- and endo-intermediates $\mathbf{9 a}, \mathbf{b}$ and $\mathbf{9 c}, \mathbf{d}$. Reagents and conditions: (i) $\mathrm{H}_{2}$, $10 \% \mathrm{Pd} / \mathrm{C}$, EtOAc for $1.5 \mathrm{~h}$ at $\mathrm{t}=55-60{ }^{\circ} \mathrm{C}$ and $p=45 \mathrm{PSI}$; (ii) $\mathrm{LiOH}, \mathrm{MeOH}, \mathrm{H}_{2} \mathrm{O}$ for $3 \mathrm{~h}$ at $\mathrm{t}=40-50{ }^{\circ} \mathrm{C}$; (iii) EtOCOCl, THF, for $10 \mathrm{~min}$ at $\mathrm{t}=-20^{\circ} \mathrm{C}$; (iv) $\mathrm{NH}_{3} \cdot \mathrm{H}_{2} \mathrm{O}, \mathrm{Et}_{3} \mathrm{~N}$, THF, for $1 \mathrm{~h}$ at $\mathrm{t}=-20^{\circ} \mathrm{C}$; (v) TFAA, THF for $3 \mathrm{~h}$ at $\mathrm{t}=0-4{ }^{\circ} \mathrm{C}$; (vi) p-TSA, $\mathrm{CH}_{3} \mathrm{CN}$ overnight at rt; acid residue removal with $\mathrm{NH}_{3}$ in DCM.

Both mixtures $\mathbf{4 a , b}$ and $\mathbf{4 c , d}$ were subjected to multistep synthetic route including common procedures of hydrogenation, saponification, amide to nitrile conversion receiving the intermediates 5-8a,b and 5-8c,d [37-39] followed by final Boc-deprotection with ptoluenesulfonic acid to afford carbonitriles $\mathbf{9 a}, \mathbf{b}($ exo-) and $\mathbf{9 c , d}($ endo-) (Figure 6), previously mentioned in [40].

Both mixtures, 9a,b and $\mathbf{9 c , d}$, were coupled with Boc-protected (R)-3-amino-4-(2,4,5trifluorophenyl)butanoic acid $\mathbf{1 0}$ under standard conditions to yield after deprotection the corresponding final compounds 12a,b and 12c,d (Figure 7).

Here we also provide a scheme for the stereoselective synthesis of $S$ - and R-exo-2azabicyclo[2.2.1] heptane-carbonitriles starting from $S$ and $R$-1-phenylethylamine, respectively. This synthetic route appears to be more promising than the necessity of isolating each resulting diastereomer from the mixture on the final step.

For the synthesis of pure 3S- and 3R-exo-2-azabicyclo[2.2.1]heptane-carbonitriles 9a and $9 \mathbf{b}$, we used the intermediates $\mathbf{6 a}$ and $\mathbf{6} \mathbf{b}$, correspondingly. The $3 S$-acid $\mathbf{6} \mathbf{a}$ was prepared from the precursor $\mathbf{1 4} \mathbf{a}$ as described in the literature $[38,41-46]$ and shown in Figure 8. The use of (R)-1-phenylethylamine 13a followed by two-step hydrogenation and saponification afforded the only isomer 14a with the desired S-configuration of carbon in 3-position. Subsequent Boc-protection step afforded to the pure isomeric intermediate 6a [42]. The intermediate of $3 R$-configuration, $\mathbf{6} \mathbf{b}$, was prepared from $\mathbf{1 3 b}$ by the analogy with $\mathbf{6 a}$ [47]. The use of another enantiomeric starting reagent (S)-1-phenylethylamine 13b afforded the pure compound $\mathbf{6 b}$ of $3 R$-Exo-configuration [45]. The following steps to prepare $\mathbf{9 a}$ and $\mathbf{9} \mathbf{b}$ were carried out by the analogy with the scheme shown in Figure 7. 


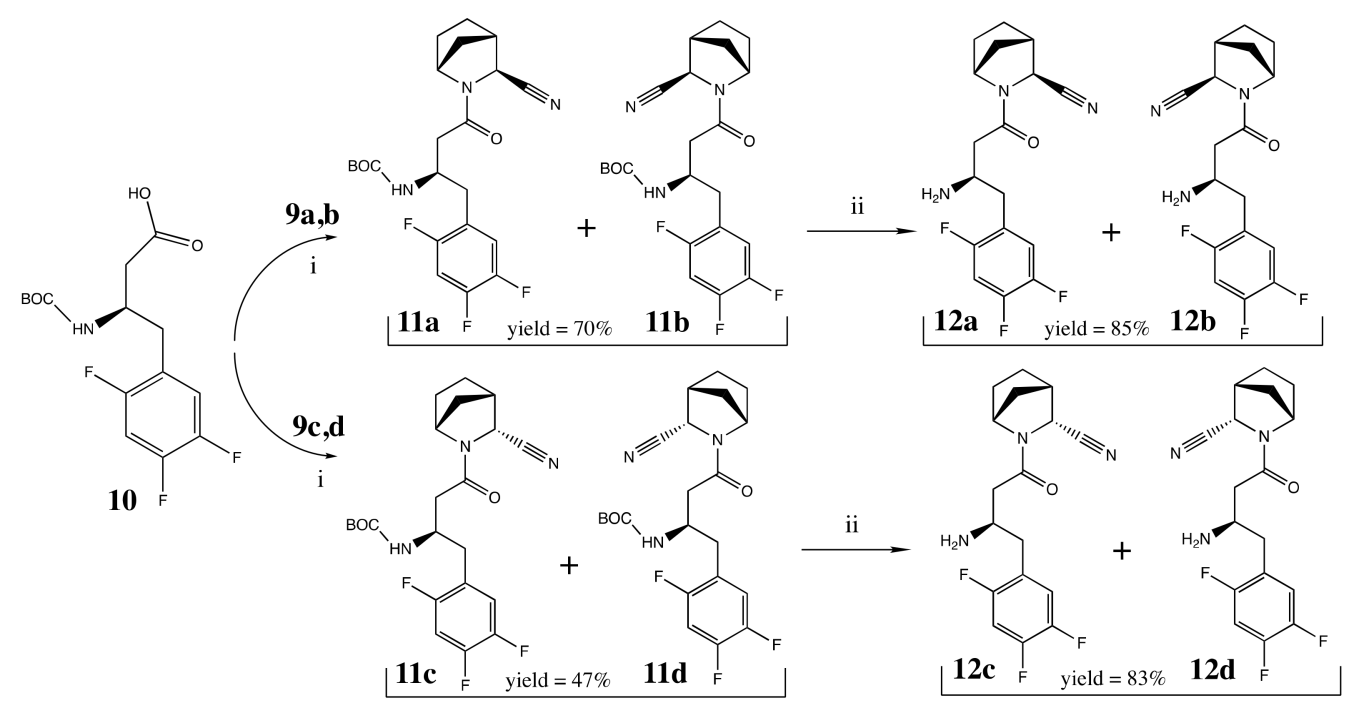

Figure 7. Synthesis of inhibitors 12a,b and 12c,d. Reagents and conditions: (i) BOP, DIPEA, DCM overnight at rt; (ii) p-TSA, $\mathrm{CH}_{3} \mathrm{CN}$ overnight at rt, products were obtained as $p$-TSA salts.

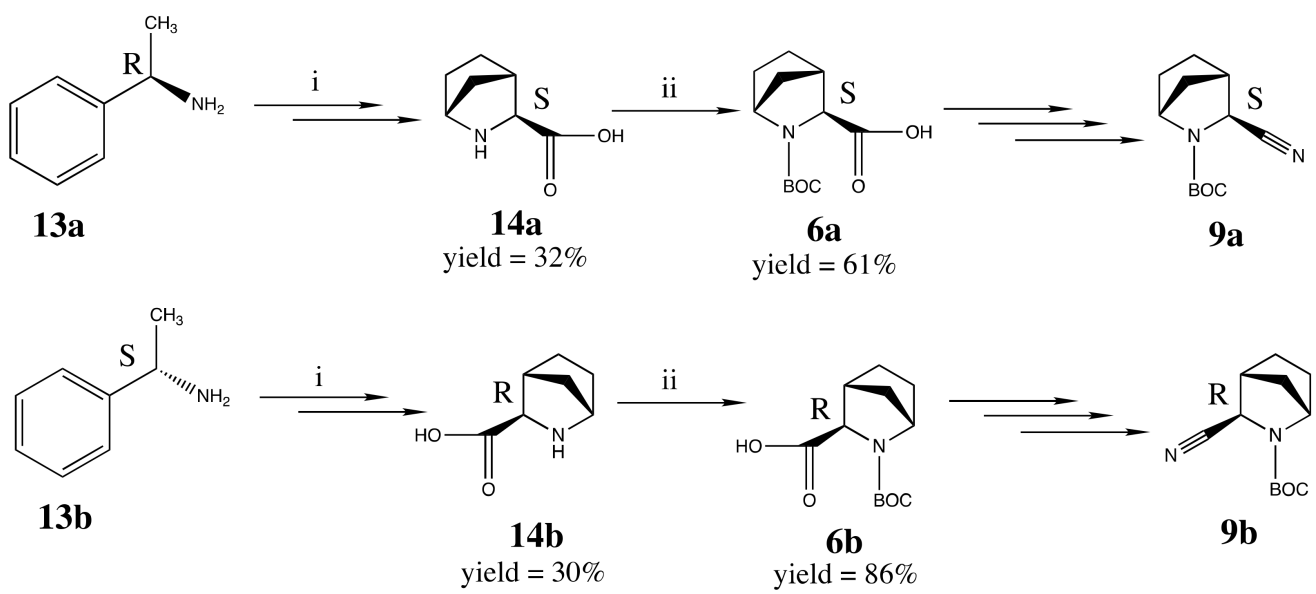

Figure 8. Synthesis of individual S-exo- and $R$-exo-stereoisomeric intermediates $6 \mathbf{a}$ and $\mathbf{6 b}$. Reagents and conditions: (i) OHC-COOEt; cyclopentadiene, $\mathrm{CF}_{3} \mathrm{COOH} / \mathrm{H}_{2} \mathrm{O}$, DMF at rt; (ii) Boc2O, EtOH for $24 \mathrm{~h}$ at rt.

The obtained individual isomeric intermediates $S$ - and $R$-exo-2-azabicyclo[2.2.1]heptanecarbonitriles $9 a$ and $\mathbf{9 b}$ were used to synthesise the corresponding individual compounds 12a and 12b.

\subsection{Structure and Purity Confirmation}

The structures of key target final compounds 12 were unambiguously confirmed by $1 \mathrm{H}, 13 \mathrm{C}\{1 \mathrm{H}\}, 13 \mathrm{C}$ apt, COSY, HSQC, and NOESY NMR spectroscopy and liquid chromatography-mass spectrometry (LC/MS) methods. For structure confirmation of their precursors, 11,1H NMR spectroscopy was applied, and in some cases, if necessary, 13C NMR spectra were also registered. In each case from compounds 11 and 12, chromatograms obtained by LC/MS analysis revealed the only molecular ion peak of $100 \%$ purity (see Supplementary file S1_NMR. Supplementary file S2_mass_spectra).

The exact assignment of individual proton signals in $1 \mathrm{H} \mathrm{NMR}$ spectra of the final compounds $\mathbf{1 2}$ and their precursors $\mathbf{1 1}$ seemed not to be an easy task due to the overlapping and complex multiplicity of most signals. The doubling of some proton signals further complicated the task-however, total intensities of the same signals precisely correlated with each other. 
Signal doubling of the identical type protons is in good accordance with the existence of equilibrium $E / Z$-rotameric forms described in the literature. It is well known (see, for example, [48]) that the introduction of the $\mathrm{N}$-acyl function in any 2-substituted pyrrolidines always leads to the formation of E/Z-rotameric forms (Figure 9a). The main reason for the stabilisation of rotamers is the hindered rotation around the $\mathrm{N}(1)-\mathrm{CO}$ amide bond, and an additional reason is a steric factor [proximity of the substituent at $\mathrm{C}(2)$ in pyrrolidine]. In most cases, the existence of equilibrium forms can be seen in $1 \mathrm{H}$ NMR spectra by doubling the corresponding proton signals (see, for example, [49]).

(a)

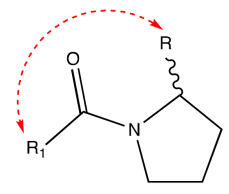

E-rotamer<smiles>O=C1PCCPC2CCCN12</smiles>

(b)

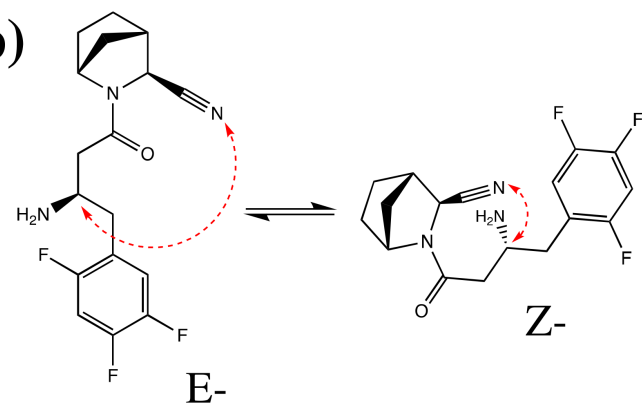

Figure 9. (a) $E / Z$ rotamers in case of $\mathrm{N}$-acylated 2-substituted pyrrolidines; (b) $E / Z$-rotameric forms of compound 12a.

All the synthesised inhibitors belonging to the class of N-acyl-2-substituted pyrrolidines should exist in solutions in E/Z-rotameric forms, as it has been shown for 12a, as an example (Figure 9b).

Indeed, the presence of rotamers of all the synthesised compounds 11a-d and $\mathbf{1 2} \mathbf{a}-\mathbf{d}$ was confirmed by registration of $1 \mathrm{H}$ NMR spectra with doubling proton signals at room temperature (see Section 3.5 and Supplementary Materials) as it is shown for 12a as an example (Figure 10).

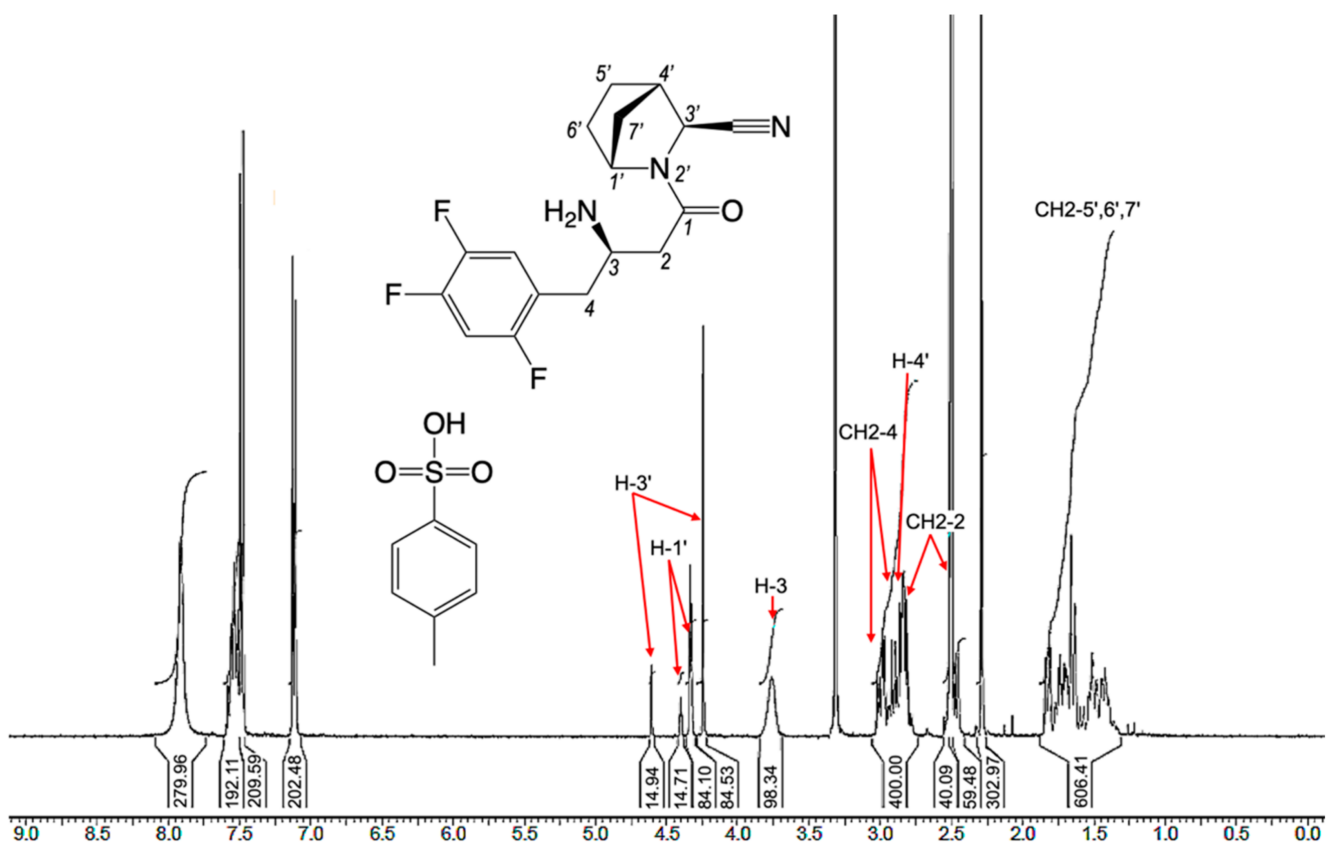

Figure 10. 1H NMR spectrum of compound 12a at room temperature.

The presence of rotameric forms was also evident in the $13 \mathrm{C}\{1 \mathrm{H}\}$ NMR spectra (see Section 3.5 and Supplementary file S1_NMR). The exact proton and carbon nuclei signals 
assignment was performed using 13C atp, COSY, HSQC, HMBC NMR spectroscopy (see Supplementary file S1_NMR).

In order to prove the existence of E/Z-rotameric forms in all the synthesised compounds, three representatives, $\mathbf{1 2} \mathbf{a}, \mathbf{1 2} \mathbf{b}$, and their mixture $\mathbf{1 2} \mathbf{a}, \mathbf{b}$, were chosen. Registration of $1 \mathrm{H}$ NMR spectra of these compounds in the temperature range $30-140{ }^{\circ} \mathrm{C}$ unambiguously confirmed the $E / Z$-rotamerism. For example, fragments of $1 \mathrm{H}$ NMR spectra of 12a in a dimethyl sulfoxide (DMSO)-d6 solution at different temperatures are shown in Figure 11. Each methine proton signal, $\mathrm{H}-\mathrm{1}^{\prime}$ and $\mathrm{H}-3^{\prime}$ (numeration in Figure 10), of the azanorbornane fragment was registered in the temperature range $30-90^{\circ} \mathrm{C}$ as two broadened singlets in the ratio of $\sim 85: 15$. The energy barrier of free rotation around the amide bond is large enough, and it is possible to overcome it only at a temperature of more than $140^{\circ} \mathrm{C}$. At a temperature of nearly $140{ }^{\circ} \mathrm{C}$, a partial coalescence of the abovementioned signals was observed.

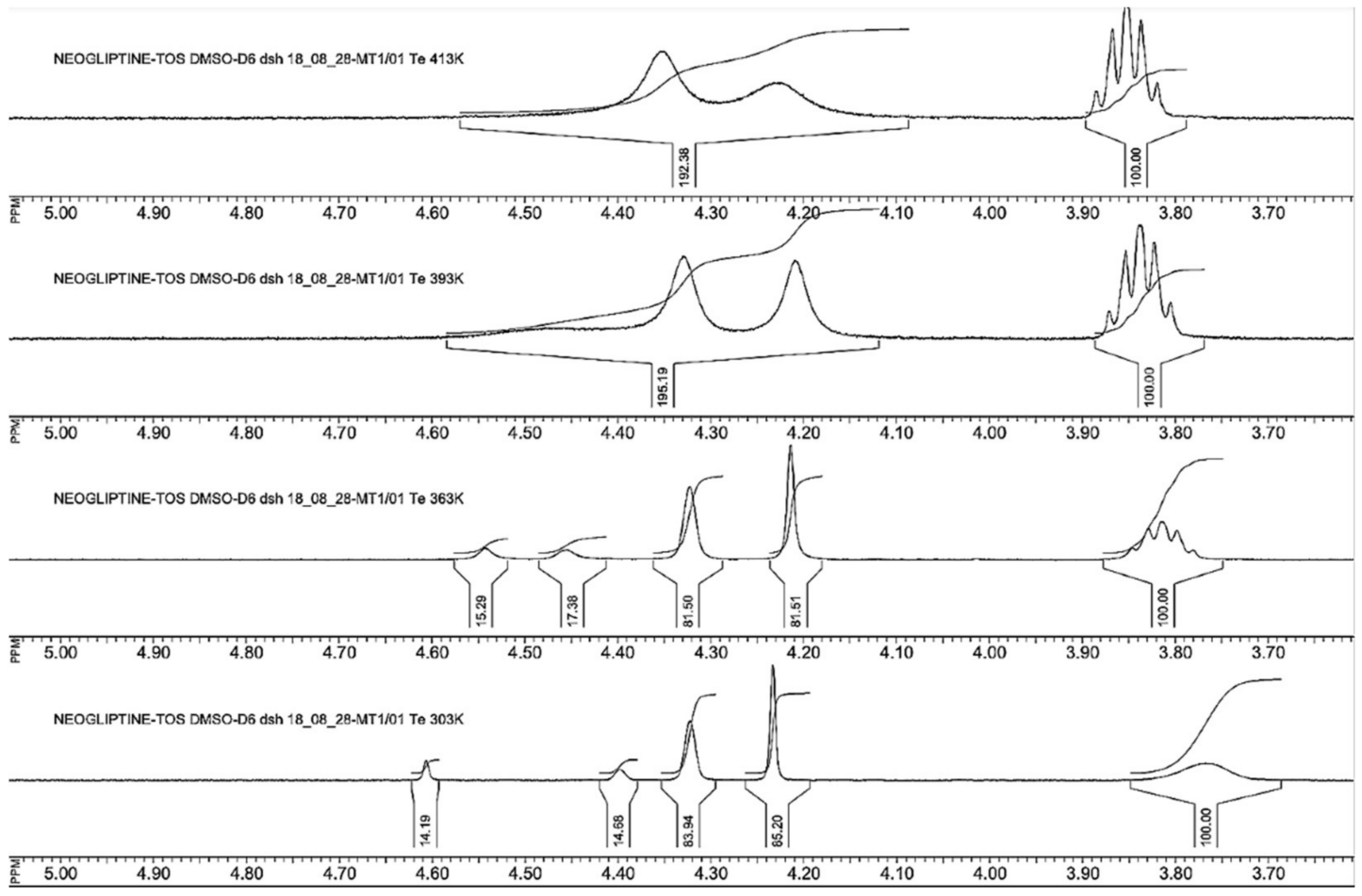

Figure 11. Fragments of $1 \mathrm{H}$ NMR spectra with $\mathrm{H}-\mathrm{1}^{\prime}, \mathrm{H}-3^{\prime}$, and $\mathrm{H}-3$ proton signals of compound 12a in the temperature range $30-140{ }^{\circ} \mathrm{C}$.

Coalescence of $\mathrm{H}-1^{\prime}$ and $\mathrm{H}-3^{\prime}$ proton signals in $1 \mathrm{H}$ NMR spectrum of $\mathbf{1 2 b}$ was also found at a temperature above $140{ }^{\circ} \mathrm{C}$ (see Supplementary materials). The ratio of $E / Z$ rotameric forms of 85:15 in DMSO-d6 solution at room temperature calculated based on $1 \mathrm{H}$ NMR data was almost the same for all the synthesised compounds, $\mathbf{1 1}$ and 12. Therefore, the data set of results obtained by NMR and LC/MS methods unambiguously confirmed that the final inhibitors $\mathbf{1 2 a}$ and $\mathbf{1 2 b}$ used for in vitro activity assay were chemically and stereochemically pure. The compounds $\mathbf{1 2 a}, \mathbf{b}$ and $\mathbf{1 2 c}, \mathbf{d}$ were diastereomeric mixtures and did not contain any side components.

\subsection{Inhibitory Activity Evaluation}

The DDP-4 enzyme inhibitory activities of the synthesised compounds were assessed using protocols similar to those described in the literature [50]. For IC50 values determination, inhibitory assays were carried out using recombinant DPP-4 enzyme D4943, chromogenic substrate Gly-Pro-pNA and buffer system (50 mM Tris- $\mathrm{HCl}, 50 \mathrm{mM} \mathrm{NaCl}$, $0.01 \%$ Triton, $\mathrm{pH}=7.6)$. After short incubation $\left(37^{\circ} \mathrm{C}\right.$ for $\left.30 \mathrm{~min}\right)$, the absorbance at $405 \mathrm{~nm}$ was measured. The procedure was initially optimised using reference compounds. Each 
inhibitor was analysed in the dilution range from $10^{-4}$ to $10^{-11} \mathrm{M}$. Certified samples of commercial drugs-inhibitors of DPP-4 (vilda-, sita-, alo- and linagliptin) with known IC50 were used as reference compounds. It was necessary to ensure that IC50 values estimated during the experiments fit into the ranges of values known for them from the literature and were reliably reproduced. Only after that precaution, synthesised compounds were tested. Correspondingly, the inhibition activity analysis of related enzymes (DPP-8 and DPP-9) was performed by fluorescent method with DPP-8 assay Kit and DPP-9 assay Kit. We analysed every compound in the dilution range $10^{-2}$ to $10^{-8} \mathrm{M}$ (Table 3).

Table 3. DPP-4-, DPP-8-, and DPP-9-inhibitory activities of target compounds 12a-d.

\begin{tabular}{|c|c|c|c|}
\hline Structure & DPP-4 $\mathrm{IC}_{50}, \mathrm{nM}$ & DPP-8 IC $_{50}, \mathrm{nM}$ & DPP-9 $\mathrm{IC}_{50}, \mathrm{nM}$ \\
\hline 12a $(S-e x o)$ & $16.8 \pm 2.2$ & $>1000$ & $>1000$ \\
\hline $\mathbf{1 2 b}(R-e x o)$ & $>1000$ & - & - \\
\hline $\begin{array}{c}\mathbf{1 2 c}(S-\text { endo }): \mathbf{1 2 d}(\text { R-endo }) \\
\text { 1:1 mixture }\end{array}$ & $>1000$ & - & - \\
\hline
\end{tabular}

\section{Materials and Methods}

\subsection{Molecular Modelling}

The docking procedure was performed using the Schrödinger Glide module in standard precision mode. The docking grid was calculated according to native ligands dimensions using available PDB models (1X70 and 6B1E). In order to perform ligand docking, protein structures were superimposed, and coordinates of the docking grid were tied to the ligand centroid. The docking area was limited per reference ligand size, with $7 \AA$ as a buffer zone. Grid spacing was set $0.375 \AA$, VdW radii cut-off $0.8 \AA$. Several optional constraints were added: nitrile group orientation (reference-vildagliptin), hydrophobic attraction-halogen-substituted moiety (sitagliptin). Docking solutions generation was performed using the Glide module of Schrödinger Suite (version 2020-3) in standard precision mode with $0.8 \AA \mathrm{VdW}$ radius and with previously mentioned optional constraints. Docking protocol was validated by redocking of reference compounds. The geometry of the best-fitting ligand was shown on ligand interaction diagrams. For each inhibitor, 45 docking solutions were generated, the best 15 were used for binding mode analysis. GlideScore and EModel values-controlled target affinity. Optimal binding poses were selected per cluster RMSD less than $1.5 \AA$. Binding pose and calculated parameters of reference ligand were taken as a control. Free Gibbs energy $(\Delta G)$ was calculated using the MM-GBSA method, implemented in Schrodinger Suite v.2020-3, module Prime. All results were processed using Maestro molecular modelling interface (Schrodinger Suite v.2020-3). All proteinligand complexes were prepared and refined using Schrodinger Protein Prepwizard. This procedure was essential to fix missing amino acid sidechains, incorrect bond orders, and correct protonation states. Optimal binding poses were selected by cluster RMSD less than $1.5 \AA$. Binding parameters of the reference ligand were selected as a control. To prove the structural novelty of identified hits, we used the Tanimoto coefficient that shows similarity scores between library compounds and already known drugs. A score below 0.5 is a good sign of low similarity. We used nine marketed gliptins (sita-, vilda-, alo-, lina-, saxa-, teneli-, trela-, evo- and omarigliptin) as reference compounds. The search for hits (top-scoring compounds with residues involved in the binding site of the enzyme with an increase in field regions) [51] was carried out in a library of chemical structures with a high level of similarity (Tanimoto coefficient more than 0.8), built on 3- azabicyclo[2.2.1]heptene-2carbonitrile scaffolds. Potential toxicity evaluation of ligands was carried out using the QikProp module, using 2D/3D-QSAR descriptor combinations analysis. 
3.1.1. Molecular Modelling Hardware

- All calculations were processed at Sechenov First Moscow State Medical University, using the following hardware:

- $\quad$ Fujitsu RX4770M3 CPU-server. Intel(R) Xeon(R) CPU E7-8867 v4 @ 2.40GHz 18C/36T x4, 1024Gb RAM.

- $\quad$ Fujitsu RX2540M4 GPU-server. Intel(R) Xeon(R) Gold 6138 CPU @ 2.00GHz 20C /80T x2, 1024Gb RAM, 2xTesla P100 16Gb.

- $\quad$ Fujitsu Celsius R940 GPU-server. Intel(R) Xeon(R) CPU E5-2690 v4 @ 2.60GHz 14C/28T x2, 256Gb RAM, 2xGTX 1080Ti 11Gb.

\subsubsection{Used Software}

- Maestro. Schrödinger Release 2020-3: Maestro, Schrödinger, LLC, New York, NY, USA, 2020.

- LigPrep. Schrödinger Release 2020-3: LigPrep, Schrödinger, LLC, New York, NY, USA, 2020.

- Prime. Schrödinger Release 2020-3: Prime, Schrödinger, LLC, New York, NY, USA, 2020.

- Glide module. Schrödinger Release 2020-3: Glide, Schrödinger, LLC, New York, NY, USA, 2020.

\subsection{Chemical Synthesis}

All starting reagents were bought from reliable commercial vendors, mostly SigmaAldrich, Merck, and Acros, and used without further purification. Intermediates and final compounds were isolated using column chromatography on silica gel. Compounds were only used for biological evaluation if the purity was $\geq 95 \%$.

\subsection{LC/MS, NMR, and Elemental Analysis}

Liquid chromatography-mass spectrometry (LC/MS), NMR spectroscopy, and elemental analysis methods were applied to confirm the structure and purity of all synthesised compounds.

LC/MS analysis was performed on an 1100 LC (Agilent Technologies) with ELSD, UV (DAD 200-400 nm), and mass detection (1100 LCMSD, Agilent Technologies, APCI, and ES positive ionization). The most used column was the Onix C18 $50 \times 4.6 \mathrm{~mm}$; eluent $1-0.1 \%$ TFA in water; eluent $2-0.1 \%$ TFA in acetonitrile, gradient-eluent $1-2.9 \mathrm{~min}$, eluent $2-0.2 \mathrm{~min}$, eluent 1 -rinsing, flow rate- $3.75 \mathrm{~mL} / \mathrm{min}$.

The structures of key target final compounds were unambiguously confirmed by $1 \mathrm{H}$, $13 \mathrm{C}\{1 \mathrm{H}\}, 13 \mathrm{C}$ apt, COSY, HSQC, and NOESY NMR spectroscopy. For structure confirmation of intermediates, $1 \mathrm{H}$ NMR spectroscopy was applied, and in some cases, if it was necessary, $13 \mathrm{C}\{1 \mathrm{H}\}$ NMR spectra were also registered. NMR spectra were registered on spectrometers Bruker DRX 400 (400.13 MHz for protons, $100.61 \mathrm{MHz}$ for carbons, 376.50 MHz for fluorine), Bruker Avance II+ 600 (600.11 MHz for protons, $150.93 \mathrm{MHz}$ for carbons), Avance IIIHD 500 (500.13 MHz for protons, $125.78 \mathrm{Mhz}$ for carbons), and spectrometer Bruker Avance III 400 UltraShield Plus (400 MHz). CDCl3 and DMSO-d6 were used as solvents.

Elemental analysis was performed on Vario MICRO cube CHNS analyser (Elementar Analysensysteme GmbH, Hanau, Germany).

\subsection{Inhibitory Activity Evaluation}

For the inhibitory assays, we used the substrate Gly-Pro-p-nitroanilide (H-Gly-PropNA HCl, G0513) and recombinant dipeptidyl peptidase-4 enzyme (D4943) that were purchased from Sigma-Aldrich (St. Louis, MO, USA). Samples containing DPP-4 (0.0015 U/well) and varying concentrations of test compounds were incubated with the chromogenic peptide substrate, G0513 (90 $\mu \mathrm{g} /$ well) in the total volume of $100 \mu \mathrm{L}$ buffer system $(50 \mathrm{mM}$ Tris- $\mathrm{HCl}, 50 \mathrm{mM} \mathrm{NaCl}, 0.01 \%$ Triton, $\mathrm{pH}=7.6$ ). The mixtures were incubated at $37^{\circ} \mathrm{C}$ for $30 \mathrm{~min}$, and the absorbance at $405 \mathrm{~nm}$ was measured using the microplate reader ChemWell 
(Awareness Technology Inc., Palm City, FL, USA). DPP-4 inhibitory activities for each test compound were calculated. IC50 values were obtained using GraphPad Prism 8 software. Inhibition activity analysis of related enzymes (DPP-8 and DPP-9) was performed using "Fluorogenic DPP-8 Assay Kit" (BPS Bioscience) and "Fluorogenic DPP-9 Assay Kit" (BPS Bioscience). The dilution range for every compound was in the $10^{-2}$ to $10^{-8} \mathrm{M}$.

\subsection{Experimental Section}

2-tert-Butyl 3-ethyl-2-azabicyclo[2.2.1]hept-5-ene-2,3-dicarboxylate (3a-d).

The synthesis was made according to the procedure described in [34-36]. To a mixture of a saturated solution of ammonium chloride (39.3 g) and a toluene solution of ethyl glyoxylate $(50 \%, 150 \mathrm{~g})$ freshly prepared cyclopentadiene $(64.7 \mathrm{~g})$. The reaction mixture was stirred for $12 \mathrm{~h}$ at room temperature, then extracted with a mixture of methyl tert-butyl ether (MTBE) and petroleum ether (PE) in a 1:3 ratio. The aqueous layer was alkalised with $\mathrm{NaOH}$ aq. solution (50\%) up to $\mathrm{pH}$ 8.0-9.0, extracted with MTBE and dried over anhydrous sodium sulphate. After solvent evaporation, the mixture of $\mathbf{3 a - d}$ was obtained as a yellow oil $(53 \%, 67 \mathrm{~g})$ and used without any purification.

2-tert-Butyl 3-ethyl (3S,R)-exo-2-azabicyclo[2.2.1]hept-5-ene-2,3-dicarboxylate $(4 \mathrm{a}, \mathrm{b})$ and 2-tert-butyl 3-ethyl (3R,S)-endo-2-azabicyclo[2.2.1]hept-5-ene-2,3-dicarboxylate (4c,d).

The synthesis was made according to the procedure described in [37]. To a solution of 3a-d (38 g) in THF (200 mL), a solution of Boc-anhydride (55 g) was added dropwise in THF (200 mL) while cooling the reaction mixture with ice. The mixture was kept overnight under stirring at room temperature, then the solvent was evaporated, and the residue was dissolved in PE: EtOAc (in 1: 1 ratio) and washed with brine. The organic layer was dried over anhydrous sodium sulphate. The obtained mixture of exo- and endo-isomers was separated using column chromatography. Eluent: PE -> PE: EtOAc 30\%. The separation afforded to pure exo-isomers $4 \mathbf{a}, \mathbf{b}(17 \mathrm{~g})$ and endo-isomers $4 \mathbf{c}, \mathbf{d}(20 \mathrm{~g})$. The total yield was 77\%. 1H NMR (400 MHz, CDCl3), $\delta$ (ppm) for 4a,b: $6.49(\mathrm{~m}, 1 \mathrm{H}), 6.37(1 \mathrm{~m}, 1 \mathrm{H}), 4.79$, $4.66(2 \mathrm{~m}, 1 \mathrm{H}$, rotameric forms $), 4.23-4.18(\mathrm{~m}, 2 \mathrm{H}), 3.48,3.39$ (2 $\mathrm{m}, 1 \mathrm{H}$, rotameric forms), $3.27(\mathrm{~m}, 1 \mathrm{H}), 1.98-1.96(\mathrm{~m}, 1 \mathrm{H}), 1.54-1.37(\mathrm{~m}, 9 \mathrm{H}+1 \mathrm{H}$, overlapped signals of rotameric forms), 1.32-1.25 (m, 3H). 1H NMR (400 MHz, CDCl3), $\delta$ (ppm) for 4c,d: 6.54, 6.51 (2 m, $1 \mathrm{H}$, rotameric forms $), 6.09(\mathrm{~m}, 1 \mathrm{H}), 4.86,4.75(2 \mathrm{~m}, 1 \mathrm{H}$, rotameric forms $), 4.32,4.26(2 \mathrm{~m}, 1 \mathrm{H}$, rotameric forms), 4.15-4.09 (m, 2H), $3.47(\mathrm{~m}, 1 \mathrm{H}), 1.67-1.65(2 \mathrm{~m}, 2 \mathrm{H}), 1.46-1.39(\mathrm{~m}, 9 \mathrm{H})$, $1.26-1.22(\mathrm{~m}, 3 \mathrm{H})$

\section{2-tert-Butyl 3-ethyl (3S,R)-exo-2-azabicyclo[2.2.1]heptane-2,3-dicarboxylate(5a,b)}

The synthesis was made according to the procedure described in [37]. A mixture of $4 a, b$ (17 g), $10 \% \mathrm{Pd} / \mathrm{C}(0.8 \mathrm{~g})$, and EtOH was hydrogenated for $1.5 \mathrm{~h}$ at $55-60{ }^{\circ} \mathrm{C}$ and under a pressure of 45 PSI. The mixture was filtered through celite and evaporated to give the product 5a,b (14.8 g, 86\%) as a yellow oil. 1H NMR (400 MHz, CDCl3), $\delta$ (ppm): 4.31-4.11 (m overlapped, 3H), 3.78-3.64 (m, 1H), $2.63(\mathrm{~m}, 1 \mathrm{H}), 1.87-1.45$ (m overlapped, 6H), 1.47, 1.42 (2 s, 9H, rotameric forms), 1.24 (m overlapped, 3H, rotameric forms). LC-MS APCI: $m / z 214[\mathrm{M}-\mathrm{t}-\mathrm{Bu}+\mathrm{H}]+, 170[\mathrm{M}-\mathrm{Boc}+\mathrm{H}]+$

\section{2-tert-Butyl 3-ethyl (3S,R)-endo-2-azabicyclo[2.2.1]heptane-2,3-dicarboxylate(5c,d)}

The synthesis was made according to the procedure described in [37,38]. A mixture $5 \mathbf{c}, \mathrm{d}(10 \mathrm{~g}, 58 \%)$ was prepared from $4 \mathbf{c}, \mathrm{d}(17 \mathrm{~g})$ by the analogy with 5a,b. $1 \mathrm{H} \mathrm{NMR}(400 \mathrm{MHz}$, $\mathrm{CDCl} 3), \delta(\mathrm{ppm}): 4.35(\mathrm{~m}, 1 \mathrm{H}), 4.24-4.10(\mathrm{~m}, 3 \mathrm{H}), 2.74(\mathrm{~m}, 1 \mathrm{H}), 2.02-1.60$ (m overlapped, $6 \mathrm{H}), 1.45,1.42$ (2 s, 9H, rotameric forms), 1.24 (m overlapped, 3H, rotameric forms). LC-MS APCI: $m / z 214[\mathrm{M}-\mathrm{t}-\mathrm{Bu}+\mathrm{H}]+, 170[\mathrm{M}-\mathrm{Boc}+\mathrm{H}]+$.

\section{(3S,R)-exo-2-(tert-Butoxycarbonyl)-2-azabicyclo[2.2.1]heptane-3-carboxylic acid (6a,b)}

The synthesis was made according to the procedure described in [37,39]. A mixture of ester 5a,b (14.8 g), and $\mathrm{LiOH}$ (monohydrate, $6.58 \mathrm{~g}$ ) in a water-methanol solution was stirred overnight at room temperature. TLC monitoring showed SM remained. Another 
1.5 equivalents of $\mathrm{LiOH}$ were added, and the mixture was kept under stirring at $40-50{ }^{\circ} \mathrm{C}$ for $2 \mathrm{~h}$. Then methanol was evaporated, the mixture was diluted with water, extracted with EtOAc, then the aqueous layer was acidified with citric acid to $\mathrm{pH} 4.0$ and extracted with DCM. After drying with sodium sulphate and removing the solvent, the desired product 6a,b (11.9 g, 89\%) was obtained. 1H NMR (400 MHz, CDCl3), $\delta$ (ppm): 4.34, 4.13 (2 m, $1 \mathrm{H}$, rotameric forms), 3.83, $3.73(2 \mathrm{~m}, 1 \mathrm{H}$, rotameric forms $), 2.92,2.73(2 \mathrm{~m}, 1 \mathrm{H}$, rotameric forms), 2.07-1.61 (m overlapped, $6 \mathrm{H}), 1.47,1.42$ (2 s, 9H, rotameric forms). LC-MS APCI: $m / z 186[\mathrm{M}-\mathrm{t}-\mathrm{Bu}+\mathrm{H}]+, 142[\mathrm{M}-\mathrm{Boc}+\mathrm{H}]+$.

(3S)-exo-2-(tert-Butoxycarbonyl)-2-azabicyclo[2.2.1] heptane-3-carboxylic acid (6a)

The synthesis was made according to the procedure described in $[42,46]$. To EtOH $(15 \mathrm{~mL})$ solution of compound $14 \mathrm{a}(0.9 \mathrm{~g}, 6.4 \mathrm{mmol}) \mathrm{BOC} 2 \mathrm{O}(1.6 \mathrm{~g}, 7.4 \mathrm{mmol})$ was added. The mixture was stirred at RT for $24 \mathrm{~h}$ and evaporated. Water $(15 \mathrm{~mL})$ was added to the residue. The product was extracted with EtOAc; then, the aqueous layer was acidified with citric acid to $\mathrm{pH} 4.0$ and extracted with DCM. After drying with sodium sulphate and removing the solvent, the desired product $6 \mathrm{a}(1 \mathrm{~g}, 61 \%)$ was obtained. 1H NMR and LC-MS are the same as described in $\mathbf{6} \mathbf{a}, \mathbf{b}$ synthesis.

\section{(3R)-exo-2-(tert-Butoxycarbonyl)-2-azabicyclo[2.2.1]heptane-3-carboxylic acid (6b)}

The synthesis was made according to the procedure described in [46,47]. Compound $\mathbf{6 b}(0.77 \mathrm{~g}, 86 \%)$ was prepared from $14 \mathbf{b}(0.8 \mathrm{~g})$ by the analogy with $6 \mathbf{6}$. $1 \mathrm{H}$ NMR spectra and LC-MS for $\mathbf{6 b}$ are the same as described in $\mathbf{6 a}, \mathbf{b}$ synthesis.

(3S,R)-endo-2-(tert-Butoxycarbonyl)-2-azabicyclo[2.2.1]heptane-3-carboxylic acid (6c,d)

The synthesis was made according to the procedure described in [37-39]. A mixture 6c,d $(4.9 \mathrm{~g}, 60 \%)$ was prepared from $5 \mathrm{c}, \mathrm{d}(9 \mathrm{~g})$ by the analogy with $\mathbf{6 a}, \mathbf{b}$. $1 \mathrm{H} \mathrm{NMR}(400 \mathrm{MHz}$, $\mathrm{CDCl} 3), \delta(\mathrm{ppm}): 4.36(\mathrm{~m}, 1 \mathrm{H}), 4.23(\mathrm{~m}, 1 \mathrm{H}), 2.84(1 \mathrm{~m}, 1 \mathrm{H}$, rotameric forms), 1.82-1.41 (m overlapped, 15H). LC-MS APCI: $m / z 141[\mathrm{M}-\mathrm{Boc}+\mathrm{H}]+$.

tert-Butyl (3S,R)-exo-3-carbamoyl-2-azabicyclo[2.2.1]heptane-2-carboxylate (7a,b)

The synthesis was made according to the procedure described in $[39,45]$. TEA $(6.54 \mathrm{~mL}$, $4.75 \mathrm{~g}$ ) was added to a solution of acid $\mathbf{6 a}, \mathbf{b}(10.3 \mathrm{~g})$ in anhydrous THF under argon atmosphere at $-20{ }^{\circ} \mathrm{C}$. Then ethyl chloroformate $(5.10 \mathrm{~g})$ was added dropwise over $10 \mathrm{~min}$. The mixture was kept undercooling for $40 \mathrm{~min}$, and aqueous ammonia (8.36 g) was added dropwise while cooling. After one hour, THF was evaporated, the residue was treated with a citric acid solution to $\mathrm{pH} 4.0$ and extracted with ethyl acetate. The combined organic solution was washed with aq. $\mathrm{NaHCO}$, dried over sodium sulphate and evaporated to give the product $7 \mathbf{a}, \mathbf{b}$ (10 g, quantitative yield) as a colourless crystalline residue. 1H NMR (400 MHz, CDCl3), $\delta$ (ppm): 6.85, 6.22 (2 broad signals, $1 \mathrm{H}$, rotameric forms), 5.90, 5.69 ( 2 broad signals, $1 \mathrm{H}$, rotameric forms), 4.23, $4.09(2 \mathrm{~m}, 1 \mathrm{H}$, rotameric forms), 3.76, 3.65 (2 m, $1 \mathrm{H}$ rotameric forms), 2.90, 2.79 (2 m, 1H, rotameric forms), 1.74-1.33 (m overlapped, $6 \mathrm{H})$, $1.46,1.44(2 \mathrm{~s}, 9 \mathrm{H}$, rotameric forms). LC-MS APCI: $m / z 141[\mathrm{M}-\mathrm{Boc}+\mathrm{H}]+$.

\section{tert-Butyl (3S,R)-endo-3-carbamoyl-2-azabicyclo[2.2.1]heptane-2-carboxylate (7c,d)}

The synthesis was made according to the procedure described in [38,39]. A mixture 7c,d (4 g, quantitative yield) was prepared from $\mathbf{6 c}, \mathbf{d}(4 \mathrm{~g})$ by the analogy with $7 \mathrm{a}, \mathbf{b} .1 \mathrm{H}$ NMR (400 MHz, CDCl3), $\delta$ (ppm): 6.25 (broad signal, 1H), 5.73 (broad signal, 1H), 4.47 (m, $1 \mathrm{H}), 4.13(\mathrm{~m}, 1 \mathrm{H}), 2.90(\mathrm{~m}, 1 \mathrm{H}), 2.04-1.51$ (m overlapped, 6H), 1.47, $1.44(2 \mathrm{~s}, 9 \mathrm{H}$, rotameric forms). LC-MS APCI: $m / z 140$ [M - Boc]+.

\section{tert-butyl (3S,R)-exo-3-cyano-2-azabicyclo[2.2.1]heptane-2-carboxylate (8a,b)}

Trifluoroacetic anhydride (14.4 g) was added dropwise to a suspension of amide $7 \mathbf{a}, \mathbf{b}$ $(10.3 \mathrm{~g})$ in anhydrous THF, at a temperature not higher than $4{ }^{\circ} \mathrm{C}$, within $10 \mathrm{~min}$. After the TLC, it became clear that the starting amide was still present, and another portion of trifluoroacetic anhydride $(9 \mathrm{~g})$ was added. The mixture was kept undercooling for $3 \mathrm{~h}$, then 
ammonium hydrogen carbonate $(45 \mathrm{~g}$ ) was added portion-wise. The mixture was subjected to column chromatography. Eluent: a mixture of PE: EtOAc 4: 1. Boc-protected nitrile 8a,b $(8.3 \mathrm{~g}, 87 \%)$ was obtained as a yellow oil. $1 \mathrm{H} \mathrm{NMR} \mathrm{(400} \mathrm{MHz,} \mathrm{CDCl3),} \delta$ (ppm): 4.34, 4.20 ( $2 \mathrm{~m}, 1 \mathrm{H}$, rotameric forms $), 4.02,3.91(2 \mathrm{~m}, 1 \mathrm{H}$, rotameric forms $), 2.85(\mathrm{~m}, 1 \mathrm{H}), 2.11-2.01$ (m overlapped, 1H), 1.81-1.48 (m overlapped, 5H,) 1.48, 1.44 (2 s, 9H, rotameric forms). Note: on ${ }^{1} \mathrm{H}$ NMR spectrum peaks of residual EtOAc are present. $13 \mathrm{C}\{1 \mathrm{H}\} \mathrm{NMR}(100 \mathrm{MHz}$, DMSO-d6), $\delta$ (ppm): 153.93, 152.64, 118.09, 81.38, 80.99, 57.65, 56.48, 52.79, 52.50, 43.23, 42.6, $37.19,36.54,30.35,30.15,28.46,28.39,26.61,26.44$. LC-MS APCI: $m / z 123$ [M - Boc + H]+. Anal. calcd for 8a,b (1:1 mixture of isomers) $\mathrm{C}_{12} \mathrm{H}_{18} \mathrm{~N}_{2} \mathrm{O}_{2} * 0.4 \mathrm{C}_{4} \mathrm{H}_{8} \mathrm{O}_{2}$ (EtOAc): C, 63.43; $\mathrm{H}, 8.30 ; \mathrm{N}, 10.88$. Found: $\mathrm{C}, 63.62 ; \mathrm{H}, 8.16 ; \mathrm{N}, 11.07 \%$. Anal. calcd for $8 \mathrm{a} \mathrm{C}_{12} \mathrm{H}_{18} \mathrm{~N}_{2} \mathrm{O}_{2}$ : C, $64.84 ; \mathrm{H}, 8.16 ; \mathrm{N}, 12.60$. Found: $\mathrm{C}, 64.95 ; \mathrm{H}, 8.39 ; \mathrm{N}, 12.77 \%$. Anal. calcd for $8 \mathbf{b} \mathrm{C}_{12} \mathrm{H}_{18} \mathrm{~N}_{2} \mathrm{O}_{2}$ : C, 64.84; H, 8.16; N, 12.60. Found: C, 65.12; H, 8.25; N, 12.37\%.

\section{tert-butyl $(3 S, R)$-endo-3-cyano-2-azabicyclo[2.2.1] heptane-2-carboxylate $(8 \mathrm{c}, \mathrm{d})$}

A mixture $8 \mathrm{c}, \mathrm{d}(1.5 \mathrm{~g}, 46 \%)$ was prepared from $6 \mathrm{c}, \mathrm{d}(3.5 \mathrm{~g})$ by the analogy with $\mathbf{8 a}, \mathbf{b}$. 1H NMR (400 MHz, CDCl3), $\delta$ (ppm): 4.38 (m, 1H), 4.26 (m, 1H), 2.81 (m, 1H), 2.02-1.53 (m overlapped, $6 \mathrm{H}), 1.47(\mathrm{~s}, 9 \mathrm{H})$. Note: on ${ }^{1} \mathrm{H}$ NMR spectrum peaks of residual EtOAc are present. 13C $\{1 \mathrm{H}\}$ NMR (100 MHz, DMSO-d6), $\delta$ (ppm): 153.40, 152.53, 118.18, 117.85, 81.35, 80.92, 57.96, 56.78, 52.37, 51.70, 41.81, 41.23, 37.79, 37.50, 30.22, 28.35, 24.04. LC-MS APCI: $\mathrm{m} / \mathrm{z} 123[\mathrm{M}-\mathrm{Boc}+\mathrm{H}]+$. Anal. calcd for $\mathbf{8 c}, \mathbf{d}\left(1: 1\right.$ mixture of isomers) $\mathrm{C}_{12} \mathrm{H}_{18} \mathrm{~N}_{2} \mathrm{O}_{2}$ * 0.1 $\mathrm{C}_{4} \mathrm{H}_{8} \mathrm{O}_{2}$ (EtOAc): C, 64.45; H, 8.20; N, 12.12. Found: C, 64.69; H, 8.32; N, $12.17 \%$.

\section{$(3 S, R)$-exo-2-azabicyclo[2.2.1]heptane-3-carbonitrile $(9 \mathrm{a}, \mathrm{b})$}

To a solution of BOC-protected nitrile $\mathbf{8 a}, \mathbf{b}(7 \mathrm{~g})$ in acetonitrile $(30 \mathrm{~mL}), \mathrm{p}$-TSA (12 $\mathrm{g}$, two-fold excess) was added. The mixture was stirred overnight. Acetonitrile was evaporated, the residue was triturated with diethyl ether (3-4 treatments with decantation). The residue was dissolved in DCM and saturated with ammonia from a balloon. The precipitated ammonium salt of $p$-TSA was filtered. The filtrate was evaporated, and the residue was purified by column chromatography. Eluent: DCM after extraction of aqueous ammonia in the ratio of 1:10. The desired product $9 \mathbf{a}, \mathbf{b}(3.2 \mathrm{~g}, 83 \%)$ was obtained as a yellow oil. 1H NMR (400 MHz, CDCl3), $\delta$ (ppm): 5.38 (broad signal, 1H), $3.58(\mathrm{~m}, 1 \mathrm{H}), 3.56$ (m, $1 \mathrm{H}), 2.72(\mathrm{~m}, 1 \mathrm{H}), 1.68(\mathrm{~m}, 2 \mathrm{H}), 1.46-1.31$ (m overlapped, $4 \mathrm{H})$. Note: on ${ }^{1} \mathrm{H}$ NMR spectrum peaks of residual N-tert-butylacetamide are present. 13C $\{1 \mathrm{H}\}$ NMR $(100 \mathrm{MHz}, \mathrm{DMSO}-d 6), \delta$ (ppm): 121.03, 55.99, 51.09, 42.44, 36.39, 32.64, 27.35. LC-MS APCI: $m / z 123$ [M + H]+. Anal. calcd for $9 \mathbf{a}, \mathbf{b}$ (1:1 mixture of isomers) $\mathrm{C}_{7} \mathrm{H}_{10} \mathrm{~N}_{2} * 0.6 \mathrm{C}_{6} \mathrm{H}_{13} \mathrm{NO}$ (N-tert-butylacetamide): $\mathrm{C}$, 66.56; H, 9.38; N, 19.04. Found: C, 66.69; H, 9.42; N, 18.95\%.

\section{(3S)-exo-2-azabicyclo[2.2.1]heptane-3-carbonitrile (9a)}

Compound 9a was prepared from 6a by the multistep synthetic route described for 9a,b. 1H NMR spectra and LC/MS for 9a are the same as described in $\mathbf{9 a}, \mathbf{b}$ synthesis. Anal. calcd for $\mathrm{C}_{7} \mathrm{H}_{10} \mathrm{~N}_{2} * 0.1 \mathrm{C}_{6} \mathrm{H}_{13} \mathrm{NO}$ (N-tert-butylacetamide): $\mathrm{C}, 68.28 ; \mathrm{H}, 8.52 ; \mathrm{N}, 22.00$. Found: C, 68.58; H, 8.67; N, 22.00\%.

\section{(3R)-exo-2-azabicyclo[2.2.1]heptane-3-carbonitrile (9b)}

Compound $9 \mathrm{~b}$ was prepared from $\mathbf{6 b}$ by the multistep synthetic route described for 9a,b. 1H NMR spectra and LC/MS for $\mathbf{9 b}$ are the same as described in $\mathbf{9 a}, \mathbf{b}$ synthesis. Anal. calcd for $\mathrm{C}_{7} \mathrm{H}_{10} \mathrm{~N}_{2}{ }^{*} 0.2 \mathrm{C}_{6} \mathrm{H}_{13} \mathrm{NO}$ (N-tert-butylacetamide): $\mathrm{C}, 67.83 ; \mathrm{H}, 8.75 ; \mathrm{N}, 21.22$. Found: C, 68.08; H, 8.87; N, 21.01\%.

\section{$(3 S, R)$-endo-2-azabicyclo[2.2.1]heptane-3-carbonitrile $(9 \mathrm{c}, \mathrm{d})$}

A mixture $9 c, d(0.4 \mathrm{~g}, 52 \%)$ was prepared from $7 \mathrm{c}, \mathbf{d}(1.4 \mathrm{~g})$ by the analogy with $\mathbf{9 a , b}$. 1H NMR (400 MHz, CDCl3), $\delta$ (ppm): 5.52 (broad signal, 1H), 3.87 (m, 1H), 3.45 (m, 1H), $2.60(\mathrm{~m}, 1 \mathrm{H}), 1.87-1.83(\mathrm{~m}, 2 \mathrm{H}), 1.63-1.50(\mathrm{~m}, 4 \mathrm{H})$. Note: on ${ }^{1} \mathrm{H}$ NMR spectrum peaks of residual N-tert-butylacetamide are present. $13 \mathrm{C}\{1 \mathrm{H}\} \mathrm{NMR}(100 \mathrm{MHz}, \mathrm{DMSO}-d 6), \delta(\mathrm{ppm})$ : 120.94, 56.67, 50.53, 40.46, 38.83, 31.57, 24.29. LC-MS APCI: $m / z 123$ [M + H]+. Anal. calcd 
for $9 c, d$ (1:1 mixture of isomers) $\mathrm{C}_{7} \mathrm{H}_{10} \mathrm{~N}_{2} * 0.3 \mathrm{C}_{6} \mathrm{H}_{13} \mathrm{NO}$ (N-tert-butylacetamide): C, 67.44; H, 8.94; N, 20.56. Found: C, 67.68; H, 8.94; N, 20.64\%.

tert-Butyl \{(3R)-4-[(3S,R)-3-cyano-exo-2-azabicyclo[2.2.1]heptan-2-yl]-1-(2,4,5-trifluoroph enyl)-4-oxobutan-2-yl)\}carbamate (11a,b)

To a solution of acid $10(0.19 \mathrm{~g}, 1 \mathrm{mmol})$ in DCM $(20 \mathrm{~mL})$ were added DIPEA $(0.13 \mathrm{~g}$, $1 \mathrm{mmol}), \mathrm{BOP}(0.44 \mathrm{~g}, 1 \mathrm{mmol})$, and amine $9 \mathbf{a}, \mathbf{b}(0.12 \mathrm{~g}, 1 \mathrm{mmol})$. The mixture was stirred at room temperature overnight and washed with $5 \%$ aqueous citric acid solution $(3 \times 10 \mathrm{~mL})$ and $10 \% \mathrm{NaHCO} 3(3 \times 10 \mathrm{~mL})$. The organic layer was dried over anh. sodium sulphate. The solvent was evaporated. The residue was dissolved in chloroform and purified by silica gel column chromatography (eluent 1-5\% $\mathrm{MeOH} / \mathrm{CHCl} 3)$ to yield 11a,b $(0.3 \mathrm{~g}, 70 \%)$. 1H NMR (400 MHz, DMSO-d6), $\delta$ (ppm): 7.46 (m, 1H, Ph), 7.29 (m, 1H, Ph), 6.86, 6.80, $6.73,6.39$ (4 m, 1H, NH-Boc, 2 diastereomers in 2 rotameric forms), 4.68, 4.57, 4.41, 4.39, $4.34,4.26,4.24$ (7 m, 2H, 2 diastereomers in 2 rotameric forms), $4.05(\mathrm{~m}, 1 \mathrm{H}), 2.94-2.78$ (m, 2H), 2.70-2.56, 2.46-2.33 (m, 3H, 2 diastereomers in 2 rotameric forms), 1.85-1.42 (m overlapped, $6 \mathrm{H}), 1.27,1.24,1.19(3 \mathrm{~m}, 9 \mathrm{H}$, Boc, 2 diastereomers in 2 rotameric forms). 13C $\{1 \mathrm{H}\}$ NMR (100 MHz, DMSO-d6), $\delta$ (ppm): 168.61, 168.32, 168.16, 154.75-154.83, 149.06, 146.77, 144.39, 122.69-122.89, 119.15-119.41, 118.52, 118.12, 105.24-105.52, 77.70, 77.63, 57.88. 57.86, 56.07, 56.03, 52.13, 51.11, 50.98, 48.17, 47.44, 47.12, 42.74, 41.61, 41.59, 37.23, 37.20, $35.34,33.17,33.13,30.49,29.28,28.11,28.05,27.76,25.53,25.51,25.19$. LC-MS APCI: $m / z$ $382[\mathrm{M}-\mathrm{t}-\mathrm{Bu}+\mathrm{H}]+, 338[\mathrm{M}-\mathrm{Boc}+\mathrm{H}]+$. Anal. calcd for 11a,b (1:1 mixture of isomers) $\mathrm{C}_{22} \mathrm{H}_{26} \mathrm{~N}_{3} \mathrm{O}_{3} \mathrm{~F}_{3}: \mathrm{C}, 60.40 ; \mathrm{H}, 5.99 ; \mathrm{N}, 9.61$. Found: C, 60.61; H, 6.04; N, 9.61\%.

tert-Butyl \{(3R)-4-[(3S)-3-cyano-exo-2-azabicyclo[2.2.1]heptan-2-yl]-1-(2,4,5-trifluorophe nyl)-4-oxobutan-2-yl)\}carbamate (11a)

Compound 11a $(0.29 \mathrm{~g}, 68 \%)$ was prepared from acid $10(0.19 \mathrm{~g}, 1 \mathrm{mmol})$ and amine 9a $(0.12 \mathrm{~g}, 1 \mathrm{mmol})$ by the analogy with 11a,b. $1 \mathrm{H} \mathrm{NMR}(600 \mathrm{MHz}, \mathrm{DMSO}-d 6), \delta$ (ppm): 7.51-7.45 (m, 1H, Ph), 7.31 (m, 1H, Ph), 6.84, 6.77, 6.39 (3 m, 1H, NH-Boc, 2 rotameric forms), 4.58, 4.26 (2 m, 1H, CHCN, 2 rotameric forms), 4.39, 4.34 (2 m, 1H, 2 rotameric forms), 4.05 (m, 1H), 2.85-2.78 (m, 2H), 2.64-2.55 (m, 2H), 2.50-2.46 (m, 1H), 1.85-1.42 (m overlapped, $6 \mathrm{H}), 1.27,1.20$ (2 m, 9H, Boc, 2 rotameric forms). LC-MS AP-ES: $m / z 382[\mathrm{M}-\mathrm{t}-\mathrm{Bu}+\mathrm{H}]+$, $338[\mathrm{M}-\mathrm{Boc}+\mathrm{H}]+$. Anal. calcd for $\mathrm{C}_{22} \mathrm{H}_{26} \mathrm{~N}_{3} \mathrm{O}_{3} \mathrm{~F}_{3}: \mathrm{C}, 60.40 ; \mathrm{H}, 5.99 ; \mathrm{N}, 9.61$. Found: $\mathrm{C}$, $60.55 ; \mathrm{H}, 6.11 ; \mathrm{N}, 9.36 \%$.

tert-Butyl \{(3R)-4-[(3R)-3-cyano-exo-2-azabicyclo[2.2.1]heptan-2-yl]-1-(2,4,5-trifluorophe nyl)-4-oxobutan-2-yl)\}carbamate (11b)

Compound $11 \mathrm{~b}(0.28 \mathrm{~g}, 65 \%)$ was prepared from acid $10(0.19 \mathrm{~g}, 1 \mathrm{mmol})$ and amine $9 \mathbf{b}(0.12 \mathrm{~g}, 1 \mathrm{mmol})$ by the analogy with 11a,b. 1H NMR (500 MHz, DMSO-d6), $\delta$ (ppm): 7.52-7.43 (m, 1H, Ph), 7.30 (m, 1H, Ph), 6.86, 6.80, 6.42 (3 m, 1H, NH-Boc, 2 rotameric forms), 4.68, 4.42 (2 m, 1H, CHCN, 2 rotameric forms), 4.39, 4.25 (2 m, 1H, 2 rotameric forms), 4.03 (m, 1H), 2.95-2.83 (m, 2H), 2.69-2.55 (m, 2H), 2.40-2.34 (m, 1H), 1.86-1.42 (m overlapped, $6 \mathrm{H}), 1.28,1.25,1.19$ (3 m, 9H, Boc, rotameric forms). LC-MS APCI: $m / z 382$ [M - t-Bu + H]+, $338[\mathrm{M}-\mathrm{Boc}+\mathrm{H}]+$. Anal. calcd for $\mathrm{C}_{22} \mathrm{H}_{26} \mathrm{~N}_{3} \mathrm{O}_{3} \mathrm{~F}_{3}: \mathrm{C}, 60.40 ; \mathrm{H}, 5.99 ; \mathrm{N}, 9.61$. Found: $\mathrm{C}$, $60.65 ; \mathrm{H}, 6.06 ; \mathrm{N}, 9.73 \%$.

tert-Butyl $\{(3 R)-4-[(3 S, R)-3-c y a n o-e n d o-2-a z a b i c y c l o[2.2 .1] h e p t a n-2-y 1]-1-(2,4,5-t r i f l u o r o$ phenyl)-4-oxobutan-2-yl)\}carbamate (11c,d)

A mixture 11c,d $(0.2 \mathrm{~g}, 47 \%)$ was prepared from acid $10(0.19 \mathrm{~g}, 1 \mathrm{mmol})$ and amine 9c,d (0.12 g, $1 \mathrm{mmol})$ by the analogy with 11a,b. 1H NMR (600 MHz, DMSO-d6), $\delta$ (ppm): 7.42 (m, 1H, Ph), 7.29 (m, 1H, Ph), 6.71, 6.33 (2 m, 1H, NH-Boc, 2 diastereomers), 4.85, 4.62, $4.59,4.46,4.44,4.41,4.34(7 \mathrm{~m}, 2 \mathrm{H}, 2$ diastereomers in 2 rotameric forms $), 4.02(\mathrm{~m}, 1 \mathrm{H})$, 2.96-2.84 (m, 2H), 2.66-2.54 (m, 2H), 2.50-2.43 (m, 1H), 1.75-1.57 (m overlapped, 6H), 1.29, $1.28,1.22$ (3 m, 9H, H-Boc, 2 diastereomers in 2 rotameric forms). $13 \mathrm{C}\{1 \mathrm{H}\} \mathrm{NMR}(100 \mathrm{MHz}$, DMSO-d6), $\delta$ (ppm): 167.61, 167.55, 157.23-157.38, 154.85, 154.83, 154.16, 148.84-149.28, 146.52-146.95, 144.39-144.60, 122.64-122.98, 119.20-119.47, 118.04, 117.96, 105.27-105.79, 
$103.13,77.73,77.71,63.02,58.27,58.16,50.67,50.61,47.59,47.47,39.98,39.95,37.49,37.35$, $33.19,33.03,30.10,29.98,28.15,28.12,27.79,23.62,18.47,15.39$. LC-MS APCI: $m / z 382$ $[\mathrm{M}-\mathrm{t}-\mathrm{Bu}+\mathrm{H}]+, 338[\mathrm{M}-\mathrm{Boc}+\mathrm{H}]+$. Anal. calcd for 11c,d (1:1 mixture of isomers) $\mathrm{C}_{22} \mathrm{H}_{26} \mathrm{~N}_{3} \mathrm{O}_{3} \mathrm{~F}_{3}: \mathrm{C}, 60.40 ; \mathrm{H}, 5.99 ; \mathrm{N}, 9.61$. Found: C, 60.24; $\mathrm{H}, 6.12 ; \mathrm{N}, 9.73 \%$.

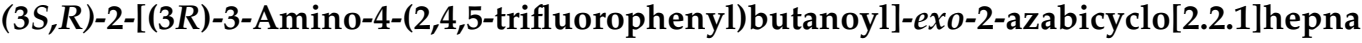
ne-3-carbonitrile $p$-toluenesulpfonate $(12 a, b)$

Compound 11a,b $(0.30 \mathrm{~g}, 0.69 \mathrm{mmol})$ was dissolved in acetonitrile $(20 \mathrm{~mL})$ and p-TSA ( 2 eq.) was added. The mixture was stirred at room temperature overnight. The precipitate was filtered off, washed with diethyl ether and dried in vacuo to give $\mathbf{1 2} \mathbf{a}, \mathbf{b}$ as $\mathbf{p}$-TSA-salt (0.3 g, 85\%). 1H NMR (500 MHz, DMSO-d6): $\delta 7.93$ (br.s, 3H, NH3+), 7.56-7.48 (m + d overlapped, 4H, Jd = $4 \mathrm{~Hz}), 7.12(\mathrm{~d}, 2 \mathrm{H}, \mathrm{Jd}=4 \mathrm{~Hz}), 4.61,4.58,4.40,4.34,4.30,4.27,4.25$ $(7 \mathrm{~m}, 2 \mathrm{H}, 2$ diastereomers in 2 rotameric forms $), 3.76(\mathrm{~m}, 1 \mathrm{H}), 3.02-2.82(\mathrm{~m}, 4 \mathrm{H}), 2.57-2.46$ $(\mathrm{m}, 1 \mathrm{H}), 2.29$ (c, 3H), 1.83-1.40 (m, 6H). 13C $\{1 \mathrm{H}\}$ NMR (125 MHz, DMSO-d6), $\delta(\mathrm{ppm})$ : 168.02, 167.79, 157.62-157.55, 155.73-155.61, 150.08-149.95, 148.04-147.94, 148.36-147.46, $140.05,145.57-145.43,138.18,128.56,125.96,120.32-119.96,118.26,106.76-106.35,58.26$, $58.20,56.81,52.13,51.59,47.72,47.49,43.35,41.93,37.61,37.19,35.99,35.67,31.39,30.54$, $30.44,29.42,25.96,25.83,25.47,21.25$. 19F NMR (376 MHz, DMSO-d6), $\delta$ (ppm): -117.71, -118.01 (2 m, 2 diastereomers), -135.71, -136.02 (2 m, 2 diastereomers), -143.21, -143.35 ( 2 m, 2 diastereomers). LC-MS APCI: $m / z 338[\mathrm{M}+\mathrm{H}]+$. Anal. calcd for 12a,b (1:1 mixture of isomers) $\mathrm{C}_{24} \mathrm{H}_{26} \mathrm{~F}_{3} \mathrm{~N}_{3} \mathrm{O}_{4} \mathrm{~S}$ : C, 56,57; $\mathrm{H}, 5.14 ; \mathrm{N}, 8.25 ; \mathrm{S}, 6.29$. Found: $\mathrm{C}, 56.70 ; \mathrm{H}, 5.28 ; \mathrm{N}$, $8.08 ; \mathrm{S}, 6.48 \%$.

(3S)-2-[(3R)-3-Amino-4-(2,4,5-trifluorophenyl)butanoyl]-exo-2-azabicyclo[2.2.1]hepnane-3carbonitrile $p$-toluenesulpfonate (12a)

Compound 12a $(0.15 \mathrm{~g}, 84 \%)$ was prepared from 11a $(0.15 \mathrm{~g}, 0.35 \mathrm{mmol})$ by the analogy with 12a,b. 1H NMR (400 MHz, DMSO-d6): $\delta 7.94$ (br.s, 3H, NH3+), 7.59-7.48 $(\mathrm{m}+\mathrm{d}$ overlapped, $4 \mathrm{H}), 7.13(\mathrm{~d}, 2 \mathrm{H}, \mathrm{Jd}=4 \mathrm{~Hz}), 4.61,4.24(2 \mathrm{~m}, 1 \mathrm{H}, 2$ rotameric forms $)$, 4.40, $4.33(2 \mathrm{~m}, 1 \mathrm{H}, 2$ rotameric forms), $3.76(\mathrm{~m}, 1 \mathrm{H}), 3.02-2.81(\mathrm{~m}, 4 \mathrm{H}), 2.55-2.46(\mathrm{~m}, 1 \mathrm{H})$, 2.29 (c, 3H), 1.83-1.37 (m, 6H). 13C $\{1 \mathrm{H}\}$ NMR (100 MHz, DMSO-d6), $\delta$ (ppm): 167.33, 157.31-157.44, 154.93-155.03, 149.56-149.90, 147.19-147.35, 145.56, 144.74-144.90, 137.77, $128.11,125.51,119.48-119.92,117.79,105.83-106.33,57.77,56.36,51.70,51.16,47.33,47.13$, $42.95,41.52,37.11,35.51,35.32,35.25,31.14,30.94,30.11,28.98,25.52,25.04,20.79 \mathrm{LC} / \mathrm{MS}$ APCI: $m / z 338[\mathrm{M}+\mathrm{H}]+$. Anal. calcd for $\mathrm{C}_{24} \mathrm{H}_{26} \mathrm{~F}_{3} \mathrm{~N}_{3} \mathrm{O}_{4} \mathrm{~S}: \mathrm{C}, 56,57 ; \mathrm{H}, 5.14 ; \mathrm{N}, 8.25 ; \mathrm{S}, 6.29$. Found: C, 56.70; H, 5.17; N, 8.13; S, 6.21\%. HPLC: Shimadzu LC-2010, Column: Discovery Cyano $150 \times 4.6 \mathrm{~mm}, 5 \mu \mathrm{m}$ (Supelco), flow rate $-0.9 \mathrm{~mL} / \mathrm{min}$, column temperature $-25{ }^{\circ} \mathrm{C}$, Detection-UV, $205 \mathrm{~nm}$, sample volume-5 $\mu$ l, elution mode-isocratic, chromatography time-20 min. Purity of 12a-99.891\%.

(3R)-2-[(3R)-3-Amino-4-(2,4,5-trifluorophenyl)butanoyl]-exo-2-azabicyclo[2.2.1]hepnane-3carbonitrile $p$-toluenesulpfonate (12b)

Compound $\mathbf{1 2 b}(0.14 \mathrm{~g}, 78 \%)$ was prepared from $\mathbf{1 1 b}(0.15 \mathrm{~g}, 0.35 \mathrm{mmol})$ by the analogy with 12a,b. 1H NMR (400 MHz, DMSO-d6): $\delta 7.92$ (br.s, 3H, NH3+), 7.59 (m, 2H), 7.48 (d, $2 \mathrm{H}, \mathrm{Jd}=8 \mathrm{~Hz}), 7.11(\mathrm{~d}, 2 \mathrm{H}, \mathrm{Jd}=8 \mathrm{~Hz}), 4.57,4.27(2 \mathrm{~m}, 1 \mathrm{H}, 2$ rotameric forms $), 4.38,4.30$ ( $2 \mathrm{~m}, 1 \mathrm{H}, 2$ rotameric forms), $3.73(\mathrm{~m}, 1 \mathrm{H}), 2.99-2.67$ (m overlapped, 4H), 2.55-2.52 (m, 1H), 2.29 (c, 3H), 1.86-1.38 (m, 6H). 13C $\{1 \mathrm{H}\}$ NMR (100 MHz, DMSO-d6), $\delta$ (ppm): 167.59, 167.42, 157.40-157.52, 154.98-155.08, 149.73-149.94, 147.16-147.45, 147.57, 144.74-144.93, $137.82,128.17,125.54,119.48-119.81,117.96,105.88-106.39,57.85,56.29,51.87,51.18,47.51$, 42.94, 41.55, 37.21, 35.22, 34.97, 30.85, 30.05, 29.13, 25.43, 25.13, 20.85. LC-MS AP-ES: $\mathrm{m} / \mathrm{z}$ $338[\mathrm{M}+\mathrm{H}]+$. Anal. calcd for $\mathrm{C}_{24} \mathrm{H}_{26} \mathrm{~F}_{3} \mathrm{~N}_{3} \mathrm{O}_{4} \mathrm{~S}: \mathrm{C}, 56,57 ; \mathrm{H}, 5.14 ; \mathrm{N}, 8.25 ; \mathrm{S}, 6.29$. Found: $\mathrm{C}$, 56.87; H, 5.16; N, 8.12; S, 6.50\%. 


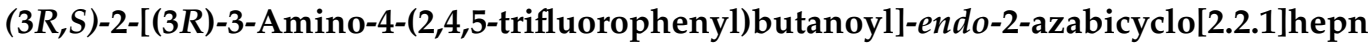
ane-3-carbonitrile $p$-toluenesulpfonate $(12 c, d)$

Compound 12c,d as p-TSA-salt $(0.29 \mathrm{~g}, 83 \%)$ was prepared from $\mathbf{1 1 c}, \mathbf{d}(0.30 \mathrm{~g}, 0.69 \mathrm{mmol})$ by the analogy with 12a,b. 1H NMR (400 MHz, DMSO-d6): $\delta 7.95$ (br.s, 3H, NH3+), 7.57-7.48 (m + d overlapped, 4H), $7.13(\mathrm{~d}, 2 \mathrm{H}, \mathrm{Jd}=8 \mathrm{~Hz}), 4.86,4.54,4.47,4.28(4 \mathrm{~m}, 2 \mathrm{H}$, 2 diastereomers in 2 rotameric forms), 3.83-3.76 (m, 1H), 3.02-2.56 (m overlapped, 5H), $2.29(\mathrm{c}, 3 \mathrm{H}), 1.73-1.50(\mathrm{~m}, 6 \mathrm{H}) .13 \mathrm{C}\{1 \mathrm{H}\}$ NMR (100 MHz, DMSO-d6), $\delta$ (ppm): 167.01, 166.55, 157.38-157.49, 154.96-155.08, 149.68-150.06, 147.16-147.50, 145.50, 144.74-144.91, 137.87, 128.17, 125.54, 119.50-119.88, 117.63, 105.85-106.35, 58.01, 55.93, 51.34, 50.70, 47.52, 47.43, 47.34, 41.50, 39.92, 37.28, 35.79, 35.07, 34.39, 31.03, 30.91, 29.78, 29.07, 23.82, 23.47, 20.84. LC/MS APCI: $m / z 338[\mathrm{M}+\mathrm{H}]+$. Anal. calcd for 12c,d (1:1 mixture of isomers) $\mathrm{C}_{24} \mathrm{H}_{26} \mathrm{~F}_{3} \mathrm{~N}_{3} \mathrm{O}_{4} \mathrm{~S}: \mathrm{C}, 56.57 ; \mathrm{H}, 5.14 ; \mathrm{N}, 8.25 ; \mathrm{S}, 6.29$. Found: $\mathrm{C}, 56.54 ; \mathrm{H}, 5.32 ; \mathrm{N}, 8.01 ; \mathrm{S}, 6.35 \%$.

\section{Conclusions}

Here we show that pseudo peptides containing trifluoro-substituted aromatic $\beta$ amino acid and the proline functional analogue (with a labile nitrile group) inhibit DPP-4. Interestingly, the Exo-isomeric derivatives within all these groups were more potent against DPP-4 than the corresponding endo-analogues. Moreover, we found that the S-configuration of the amine part was the most favourable in all the experiments. The maximum similarity score of 0.38 was obtained for compounds $12 \mathrm{a}$ and evogliptin among all the pairs (a synthesised compound + already known drug). Therefore, all our synthesised compounds can be considered significantly different compared to marketed gliptins.

The IC50 of compound 12a is in the same range as for reference compounds, and this is consistent with literature data [9,48,52-55]. As for DPP-8, 12a showed feeble inhibitory activity in the concentration range $10^{-3}-10^{-6} \mathrm{M}$, and for a homologous enzyme DPP-9 in concentration $10^{-3} \mathrm{M}$. This is significantly below the estimated therapeutic range and is consistent with literature data for already known DPP-4 inhibitor compounds [55]. This makes it possible to predict the absence of side effects associated with undesirable inhibition of homologous enzymes DPP-8 and DPP-9.

We revealed and proved the presence of $E / Z$-rotameric forms in a solution. The energy barrier of free rotation around the amide bond is large enough, and it is possible to overcome it only at a temperature of more than $140^{\circ} \mathrm{C}$. At a temperature close to $140{ }^{\circ} \mathrm{C}$, a partial coalescence of the abovementioned signals was observed. The initial studies of 12a suggest that this compound could be less toxic and more stable in aqueous solutions than marketed gliptins.

\section{Patents}

Patent (Russian Federation), Issue No. 2018134266, date of issue 28.09.2018, date of registration in the State Register of Inventions (RU) 24.01.2020, date of expiry 28.09.2038. Dipeptidyl peptidase-4 inhibitor for treating type 2 diabetes mellitus, compounds (versions) / / Patentee: Neobiotek LLC (Moscow, Russia). Authors: Trukhan V.M., Zinevich T.V., Maslov I.O., Kirichenko O.G.

Supplementary Materials: The following supporting information can be downloaded at: https:/ / www.mdpi.com/article/10.3390/ph15030273/s1, Supplementary file S1_NMR. Supplementary file S2 _mass_spectra.

Author Contributions: Data curation, I.O.M., T.V.Z., O.G.K., M.V.T., N.O.T. and V.M.T.; formal analysis and validation, I.O.M., T.V.Z., S.V.S., M.A.G. and Y.B.P.; writing-original draft preparation, I.O.M. and T.V.Z.; writing-review and editing, A.D.D., H.B.S. and V.M.T.; visualization, I.O.M.; conceptualization, supervision, funding acquisition, V.M.T. and H.B.S. All authors have read and agreed to the published version of the manuscript.

Funding: Funding was provided by LLC “Neobiotek” (Russia). HBS is supported by the Swedish Research Council and the Novo Nordisk Foundation. MAG and YBP are financed by the Ministry of Science and Higher Education of the Russian Federation within the framework of state support for 
the creation and development of World-Class Research Centres "Digital Biodesign and personalised healthcare" No. 075-15-2020-926.

Institutional Review Board Statement: Not applicable.

Informed Consent Statement: Not applicable.

Data Availability Statement: The data presented in this study are available in the article and in the supplementary materials.

Acknowledgments: We thank the I.M. Sechenov First Moscow State Medical University and Chembridge Corp. for necessary resources, infrastructure and support.

Conflicts of Interest: V.M.T., T.V.Z, I.O.M. and O.G.K. are the authors of Patent (Russian Federation), Issue No. 2018134266. The remaining authors have no conflicts of interest to declare.

\section{References}

1. Hauser, A.S.; Attwood, M.M.; Rask-Andersen, M.; Schiöth, H.B. Trends in GPCR drug discovery: New agents, targets and indications. Nat. Rev. Drug Discov. 2019, 16, 829-842. [CrossRef]

2. Rask-Andersen, M.; Almén, M.S.; Schiöth, H.B. Trends in the exploitation of novel drug targets. Nat. Rev. Drug Discov. 2011, 10, 579-590. [CrossRef]

3. Kaur, P.; Mittal, A.; Nayak, S.K.; Vyas, M.; Mishra, V.; Khatik, G.L. Current strategies and drug targets in the management of type 2 diabetes mellitus. Curr. Drug Targets 2018, 19, 1738-1766. [CrossRef]

4. Green, B.D.; Flatt, P.R.; Bailey, C.J. Dipeptidyl peptidase IV (DPP IV) inhibitors: A newly emerging drug class for the treatment of type 2 diabetes. Diab. Vasc. Dis. Res. 2006, 3, 159-165. [CrossRef]

5. Wu, D.; Li, L.; Liu, C. Efficacy and safety of dipeptidyl peptidase-4 inhibitors and metformin as initial combination therapy and as monotherapy in patients with type 2 diabetes mellitus: A meta-analysis. Diabetes Obes. Metab. 2014, 16, 30-37. [CrossRef]

6. Ahrén, B. DPP-4 inhibition and the path to clinical proof. Front. Endocrinol. 2019, 10, 1-18. [CrossRef]

7. Shimizu, S.; Hosooka, T.; Matsuda, T.; Asahara, S.; Koyanagi-Kimura, M.; Kanno, A.; Bartolome, A.; Etoh, H.; Fuchita, M.; Teruyama, K.; et al. DPP4 inhibitor vildagliptin preserves $\beta$-cell mass through amelioration of endoplasmic reticulum stress in C/EBPB transgenic mice. J. Mol. Endocrinol. 2012, 49, 125-135. [CrossRef]

8. De, S.; Banerjee, S.; Kumar SK, A.; Paira, P. Critical role of dipeptidyl peptidase IV: A therapeutic target for diabetes and cancer. Mini Rev. Med. Chem. 2018, 19, 88-97. [CrossRef]

9. Röhrborn, D.; Wronkowitz, N.; Eckel, J. DPP4 in diabetes. Front. Immunol. 2015, 6, 1-20. [CrossRef]

10. Raj, V.S.; Mou, H.; Smits, S.L.; Dekkers, D.H.; Müller, M.A.; Dijkman, R.; Muth, D.; Demmers, J.A.; Zaki, A.; Fouchier, R.A.; et al. Dipeptidyl peptidase 4 is a functional receptor for the emerging human coronavirus-EMC. Nature 2013, 495, 251-254. [CrossRef]

11. Upadhyay, J.; Gajjar, A. Analysis of crystal structures of dipeptidyl peptidase 4 (Dpp 4) Co- crystallized with diverse inhibitors. Int. J. Pharm. Sci. Res. 2018, 9, 4460-4471. [CrossRef]

12. Thornberry, N.; Weber, A. Discovery of JANUVIA (Sitagliptin), a selective dipeptidyl peptidase IV inhibitor for the treatment of type 2 diabetes. Curr. Top. Med. Chem. 2007, 7, 557-568. [CrossRef] [PubMed]

13. Augeri, D.J.; Robl, J.A.; Betebenner, D.A.; Magnin, D.R.; Khanna, A.; Robertson, J.G.; Wang, A.; Simpkins, L.M.; Taunk, P.; Huang, Q.; et al. Discovery and preclinical profile of saxagliptin (BMS-477118): A highly potent, long-acting, orally active dipeptidyl peptidase IV inhibitor for the treatment of type 2 diabetes. J. Med. Chem. 2005, 48, 5025-5037. [CrossRef] [PubMed]

14. Feng, J.; Zhang, Z.; Wallace, M.B.; Stafford, J.A.; Kaldor, S.W.; Kassel, D.B.; Navre, M.; Shi, L.; Skene, R.J.; Asakawa, T.; et al. Discovery of alogliptin: A potent, selective, bioavailable, and efficacious inhibitor of dipeptidyl peptidase IV. J. Med. Chem. 2008, 51, 4357. [CrossRef]

15. Eckhardt, M.; Langkopf, E.; Mark, M.; Tadayyon, M.; Thomas, L.; Nar, H.; Pfrengle, W.; Guth, B.; Lotz, R.; Sieger, P.; et al. 8-(3-(R)-aminopiperidin-1-yl)-7-but-2-ynyl-3-methyl-1-(4-methyl-quinazolin- 2-ylmethyl)-3,7-dihydropurine-2,6-dione (BI 1356), a highly potent, selective, long-acting, and orally bioavailable DPP-4 inhibitor for the treatment of type 2 diabetes. J. Med. Chem. 2007, 50, 6450-6453. [CrossRef]

16. Packer, M. Do DPP-4 inhibitors cause heart failure events by promoting adrenergically mediated cardiotoxicity? Clues from laboratory models and clinical trials. Circ. Res. 2018, 122, 928-932. [CrossRef]

17. Hussain, H.; Abbas, G.; Green, I.R.; Ali, I. Dipeptidyl peptidase IV inhibitors as a potential target for diabetes: Patent review (2015-2018). Expert Opin. Ther. Pat. 2019, 29, 535-553. [CrossRef]

18. Mishra, A.; Cross, M.; Hofmann, A.; Coster, M.J.; Karim, A.; Sattar, A. Identification of a novel scaffold for inhibition of dipeptidyl peptidase-4. J. Comput. Biol. 2019, 26, 1470-1486. [CrossRef]

19. Schwehm, C.; Li, J.; Song, H.; Hu, X.; Kellam, B.; Stocks, M.J. Synthesis of new DPP-4 inhibitors based on a novel tricyclic scaffold. ACS Med. Chem. Lett. 2015, 6, 324-328. [CrossRef] 
20. Berger, J.P.; SinhaRoy, R.; Pocai, A.; Kelly, T.M.; Scapin, G.; Gao, Y.D.; Pryor, K.A.D.; Wu, J.K.; Eiermann, G.J.; Xu, S.S. A comparative study of the binding properties, dipeptidyl peptidase-4 (DPP-4) inhibitory activity and glucose-lowering efficacy of the DPP-4 inhibitors alogliptin, linagliptin, saxagliptin, sitagliptin and vildagliptin in mice. Endocrinol. Diabetes Metab. 2018, 1, e00002. [CrossRef]

21. Musoev, A.; Numonov, S.; You, Z.; Gao, H. Discovery of novel DPP-IV inhibitors as potential candidates for the treatment of type 2 diabetes mellitus predicted by 3D QSAR pharmacophore models, molecular docking and de novo evolution. Molecules 2019, 24, 2870. [CrossRef] [PubMed]

22. Houck, J.D.; Dawson, T.K.; Kennedy, A.J.; Kharel, Y.; Naimon, N.D.; Field, S.D.; Lynch, K.R.; Macdonald, T.L. Structural requirements and docking analysis of amidine-based sphingosine kinase 1 inhibitors containing oxadiazoles. ACS Med. Chem. Lett. 2016, 7, 487-492. [CrossRef] [PubMed]

23. Patel, B.D.; Bhadada, S.V.; Ghate, M.D. Design, synthesis and anti-diabetic activity of triazolotriazine derivatives as dipeptidyl peptidase-4 (DPP-4) inhibitors. Bioorg. Chem. 2017, 72, 345-358. [CrossRef] [PubMed]

24. Akhtar, J.; Khan, A.A.; Ali, Z.; Haider, R.; Shahar Yar, M. Structure-activity relationship (SAR) study and design strategies of nitrogen-containing heterocyclic moieties for their anticancer activities. Eur. J. Med. Chem. 2017, 125, 143-189. [CrossRef] [PubMed]

25. Liang, G.B.; Qian, X.; Biftu, T.; Singh, S.; Gao, Y.D.; Scapin, G.; Patel, S.; Leiting, B.; Patel, R.; Wu, J.; et al. Discovery of new binding elements in DPP-4 inhibition and their applications in novel DPP-4 inhibitor design. Bioorganic Med. Chem. Lett. 2008, 18, 3706-3710. [CrossRef]

26. Li, N.; Wang, L.J.; Jiang, B.; Guo, S.J.; Li, X.Q.; Chen, X.C.; Luo, J.; Li, C.; Wang, Y.; Shi, D.Y. Design, synthesis and biological evaluation of novel pyrimidinedione derivatives as DPP-4 inhibitors. Bioorganic Med. Chem. Lett. 2018, 28, 2131-2135. [CrossRef]

27. Su, H.; Boulton, D.W.; Barros, A., Jr.; Wang, L.; Cao, K.; Bonacorsi, S.J., Jr.; Iyer, R.A.; Humphreys, W.G.; Christopher, L.J. Characterization of the in vitro and in vivo metabolism and disposition and cytochrome P450 inhibition/induction profile of saxagliptin in human. Drug Metab. Dispos. 2012, 40, 1345-1356. [CrossRef]

28. Link, J.O.; Taylor, J.G.; Xu, L.; Mitchell, M.; Guo, H.; Liu, H.; Kato, D.; Kirschberg, T.; Sun, J.; Squires, N.; et al. Discovery of ledipasvir (GS-5885): A potent, once-daily oral NS5A inhibitor for the treatment of hepatitis C virus infection. J. Med. Chem. 2014, 57, 2033-2046. [CrossRef]

29. Wang, Y.; Du, Y.; Huang, N. A survey of the role of nitrile groups in protein-ligand interactions. Future Med. Chem. 2018, 10, 2713-2727. [CrossRef]

30. Zeng, D.K.; Xiao, Q.; Li, F.Q.; Tang, Y.Z.; Jia, C.L.; Tang, X.W. Cardiovascular risk of sitagliptin in treating patients with type 2 diabetes mellitus. Biosci. Rep. 2019, 39, 2713-2728. [CrossRef]

31. Green, J.B.; Bethel, M.A.; Armstrong, P.W.; Buse, J.B.; Engel, S.S.; Garg, J.; Josse, R.; Kaufman, K.D.; Koglin, J.; Korn, S.; et al. Effect of sitagliptin on cardiovascular outcomes in type 2 diabetes. N. Engl. J. Med. 2015, 373, 232-242. [CrossRef] [PubMed]

32. Maneesha Khalse, A.B. A review on cardiovascular outcome studies of dipeptidyl peptidase-4 inhibitors. J. Clin. Endocrinol. Metab. 2018, 22, 689-695. [CrossRef]

33. Ishida, Y.; Murayama, H.; Shinfuku, Y.; Taniguchi, T.; Sasajima, T.; Oyama, N. Cardiovascular safety and effectiveness of vildagliptin in patients with type 2 diabetes mellitus: A 3-year, large-scale post-marketing surveillance in Japan. Expert Opin. Drug Saf. 2020, 19, 625-631. [CrossRef] [PubMed]

34. Hursthouse, M.B.; Malik, K.A.; Hibbs, D.E.; Roberts, S.M.; Seago, A.J.; Šik, V.; Storer, R. Reactions of ethyl 2-acetyl-2azabicyclo[2.2.1]hept-5-ene-3-carboxylate and 4-acetylamino-2-oxabicyclo[3.3.0]oct-7-en-3-one with some electrophiles. J. Chem. Soc. Perkin Trans. 1 1995, 19, 2419-2425. [CrossRef]

35. Balog, J.A.; Fairfax, D.J.; Martin, G.S.; Salvati, M.E.; Xiao, H.Y. Tricycloundecane Compounds Useful as Modulators of Nuclear Hormone Receptor Function. U.S. Patent 7,550,458, 23 June 2009.

36. Genentech, Inc. Substituted Heterocyclic Sulfonamide Compounds Useful as TRPAl Modulators. WO Patent 2015/052264, 16 April 2015.

37. Agouron Pharmaceuticals, Inc. Compunds, Compositions, and Methods for Stimulating Neuronal Growth and Elongation. WO Patent 01/40185, 7 June 2001.

38. Chu, S.S.; Alegria, L.A.; Bleckman, T.M.; Chong, W.K.M.; Duvadie, R.K.; Li, L.; Reich, S.H.; Romines, W.H.; Wallace, M.B.; Yang, Y. Thiazole Benzamide Derivatives and Pharmaceutical Compositions for Inhibiting Cell Proliferation, and Methods for Their Use. WO Patent 03/004467, 16 January 2003.

39. Vincent, M.; Remond, G.; Portevin, B.; Herve, Y.; Lepagnol, J.; Biton, C. New Heterocyclic Tripeptide Compounds. U.S. Patent 5,098,888, 24 March 1992.

40. Blondet, D.; Morin, C. Total synthesis of ( \pm )-8-aza-9a,9b-dicarbaprostaglandin H1. J. Chem. Soc. Perkin Trans. 1984, 1, 1085-1090 [CrossRef]

41. Stella, L.; Abraham, H.; Feneau-Dupont, J.; Tinant, B.; Declercq, J. Asymmetric aza-diels-alder reaction using the chiral 1-phenyl ethyl imine of methyl glyoxylate. Tetrahedron Lett. 1990, 31, 2603-2606. [CrossRef]

42. McKinnell, R.M.; Long, D.D. Hepatitis C Virus Inhibitors. WO Patent 2013/163270, 31 October 2013.

43. Alonso, D.; Bertilsson, S.; Johnsson, S.; Nordin, S.; Södergren, M.; Andersson, P. New expedient route to both enantiomers of nonproteinogenic $\alpha$-amino acid derivatives from the unsaturated 2-aza-bicyclo moiety. J. Org. Chem. 1999, 64, $2276-2280$. [CrossRef] 
44. Abbott Laboratories. Furopyridine, Thienopyridine, Pyrrolopyridine and Related Pyrimidine, Pyridazine and Triazines Compounds Useful in Controlling Chemical Synaptic Transmission. WO Patent 97/05139, 13 February 1997.

45. Novartis, A.G.; IRM LLC. Ether Derivatives of Bicyclic Heteroaryls. WO Patent 2011/029915, 17 March 2011.

46. Tararov, V.I.; Kadyrov, R.; Kadyrova, Z.; Dubrovina, N.; Börner, A. An improved synthesis of enantiopure 2-azabicyclo[2.2.1]heptane-3carboxylic acid. Tetrahedron Asymmetry 2002, 13, 25-28. [CrossRef]

47. Södergren, M.; Bertilsson, S.; Andersson, P. Allylic alcohols via catalytic asymmetric epoxide rearrangement. J. Am. Chem. Soc. 2000, 122, 6610-6618. [CrossRef]

48. Nabeno, M.; Akahoshi, F.; Kishida, H.; Miyaguchi, I.; Tanaka, Y.; Ishii, S.; Kadowaki, T. A comparative study of the binding modes of recently launched dipeptidyl peptidase IV inhibitors in the active site. Biochem. Biophys. Res. Commun. 2013, 434, 191-196. [CrossRef]

49. Singh, S.K.; Manne, N.; Pal, M. Synthesis of (S)-1-(2-chloroacetyl)pyrrolidine-2-carbonitrile: A key intermediate for dipeptidyl peptidase IV inhibitors. Beilstein J. Org. Chem. 2008, 4, 20. [CrossRef]

50. Nordhoff, S.; Bulat, S.; Cerezo-Gálvez, S.; Hill, O.; Hoffmann-Enger, B.; López-Canet, M.; Rosenbaum, C.; Rummey, C.; Thiemann, M.; Matassa, V.G.; et al. The design of potent and selective inhibitors of DPP-4: Optimization of ADME properties by amide replacements. Bioorganic Med. Chem. Lett. 2009, 19, 6340-6345. [CrossRef] [PubMed]

51. Kalhotra, P.; Chittepu, V.C.; Osorio-Revilla, G.; Gallardo-Velázquez, T. Structure-activity relationship and molecular docking of natural product library reveal chrysin as a novel dipeptidyl peptidase-4 (DPP-4) inhibitor: An integrated in silico and in vitro study. Molecules 2018, 23, 1368. [CrossRef] [PubMed]

52. Landersdorfer, C.B.; He, Y.L.; Jusko, W.J. Mechanism-based population pharmacokinetic modelling in diabetes: Vildagliptin as a tight binding inhibitor and substrate of dipeptidyl peptidase IV. Br. J. Clin. Pharmacol. 2012, 73, 391-401. [CrossRef]

53. Wang, A.; Dorso, C.; Kopcho, L.; Locke, G.; Langish, R.; Harstad, E.; Shipkova, P.; Marcinkeviciene, J.; Hamann, L.; Kirby, M.S. Potency, selectivity and prolonged binding of saxagliptin to DPP4: Maintenance of DPP4 inhibition by saxagliptin in vitro and ex vivo when compared to a rapidly-dissociating DPP4 inhibitor. BMC Pharmacol. 2012, 12, 1-11. [CrossRef]

54. Von Websky, K.; Reichetzeder, C.; Hocher, B. Linagliptin as add-on therapy to insulin for patients with type 2 diabetes. Vasc. Health Risk Manag. 2013, 9, 681-694. [CrossRef] [PubMed]

55. Komala, M.G.; Gross, S.; Zaky, A.; Pollock, C.; Panchapakesan, U. Linagliptin limits high glucose induced conversion of latent to active TGF $\beta$ through interaction with CIM6PR and limits renal tubulointerstitial fibronectin. PLoS ONE 2015, 10, e0141143. [CrossRef] 